This is the accepted manuscript of the article, which has been published in Gedrag \& Organisatie. 2019, 32(4), 250-278.

\title{
Promoting and prolonging the beneficial effects of a vacation with the help of a smartphone-based intervention
}

\author{
Anniina Virtanen \\ Tampere University, Finland \\ Jessica de Bloom \\ Tampere University, Finland University of Groningen, The Netherlands \\ Jo Annika Reins \\ Leuphana University Lüneburg, Germany \\ Christine Syrek \\ Hochschule Bonn-Rhein-Sieg, Rheinbach, Germany
}

Dirk Lehr

Leuphana University Lüneburg, Germany

Ulla Kinnunen

Tampere University, Finland

Accepted for publication in Gedrag \& Organisatie (19 September 2019) 


\section{Nederlandse samenvatting}

Het doel van dit onderzoek was om te onderzoeken of het positieve effect van vakanties op het herstel, het welbevinden en de werkprestaties van werknemers te versterken en te verlengen zijn met behulp van een smartphone-gebaseerde interventie. In een 4-weekse longitudinale studie onder 79 Finse leraren hebben wij het beloop van herstel, welbevinden, en werkprestatie vóór, tijdens, en na een vakantie onderzocht. Deelnemers werd gevraagd om een herstel-app, genaamd Holidaily, bij voorkeur dagelijks te gebruiken en vijf digitale vragenlijsten in te vullen. De groep kon verdeeld worden in niet-gebruikers, passieve gebruikers, en actieve gebruikers. Uitkomsten van de studie zijn dat de meeste herstel- en welbevinden indicatoren voor alle deelnemers verbeterden tijdens de vakantie. Werkprestatie en concentratievermogen veranderden niet na de vakantie vergeleken met ervoor. Creativiteit daalde direct na de vakantie, maar steeg anderhalve week na de vakantie tot een hoger niveau dan voor de vakantie. Actief gebruik van de app had een positief effect op enkele uitkomstmaten. Zo steeg bij actieve gebruikers hun creativiteit direct na de vakantie, terwijl dit daalde onder passieve gebruikers. Het wegebben van positieve vakantie-effecten lijkt trager onder actieve gebruikers. Maar weinig deelnemers gebruikten de app actief. Desalniettemin duiden onze resultaten erop dat een smartphone-gebaseerde herstel-interventie positieve vakantie-effecten kan verlengen. 


\section{Introduction}

Recovery from work is a decisive factor in buffering the relation between work stress and ill-health ( Sonnentag, Venz, \& Casper, 2017, for reviews). It refers to the process of lowering or eliminating strain symptoms caused by job demands and restoring employees' energetic and mental resources (Zijlstra \& Sonnentag, 2006). Vacations constitute an exceptionally powerful recovery opportunity compared to evenings after work or regular weekends, offering a relatively long absence of job demands and an opportunity to spend time on preferred non-work activities (de Bloom et al., 2009). Existing studies indicate that vacations promote employees' recovery, well-being, and job performance (Chen \& Petrick, 2013; de Bloom et al., 2009; de Bloom, Ritter, Kühnel, Reinders, \& Geurts, 2014; Hartig, Catalano, Ong, \& Syme, 2013; Kühnel \& Sonnentag, 2011). Vacationing is, for example, associated with higher life satisfaction and subjective well-being, fewer health complaints, better self-rated health, and lower levels of exhaustion after the vacation (see Chen \& Petrick, 2013, for a review). However, these beneficial effects usually fade soon after work is resumed (e.g., De Bloom et al., 2009; Reizer \& Mey-Raz, 2018). The purpose of this study was to investigate whether it is possible to strengthen and prolong the beneficial effects of recovery occurring during a vacation with the help of a smartphone-based intervention.

Our target group consisted of teachers, who form an especially stressed occupational group among knowledge workers (e.g., Kyriacou, 2001; Skaalvik \& Skaalvik, 2015; 2017). Teachers typically face job demands such as heavy workload, students’ behavioral problems, lack of autonomy, conflicts with colleagues or parents, and the increasing use of technology in teaching (e.g., Fernet et al., 2012; Klassen \& Chiu 2011; Skaalvik \& Skaalvik 2017). Teachers also spend a lot of time on work-related activities outside formal work hours (e.g., Garrick et al., 2018), which limits their recovery opportunities. However, teachers have several vacations during the school year, which gives them opportunities to recover from job strain. In this study, we focused on their one-week winter vacation. 


\subsection{Theoretical perspectives on recovery}

Research presumes two complementary processes underlying recovery from work (e.g., de Bloom, Geurts, \& Kompier, 2010). Firstly, the passive mechanism, which is based on the Effort-Recovery Model (Meijman \& Mulder, 1998), suggests that recovery only occurs when people cease to work and rest. Low demands, as well as physical and psychological disengagement from work, enable workers’ psychobiological systems to return to baseline levels (Sonnentag \& Fritz, 2015). During vacations, employees are free from immediate job demands, which gives them an opportunity for passive recovery. Secondly, the active perspective of recovery acknowledges the importance of engagement in pleasant and challenging leisure activities (Geurts \& Sonnentag, 2006). The active perspective can be grounded in theories such as Conservation of Resources Theory (Hobfoll, 1989), Broaden-and-Build Theory (Fredrickson, 2001) and Self-Determination Theory (Ryan \& Deci, 2000). According to these theories, to recover from work stress, employees need to replenish threatened resources and engage in activities, which produce positive emotions and satisfy their basic needs for autonomy, relatedness and competence. Behavioral activation also highlights the importance of engaging in valued and enjoyable activities (Mazzucchelli, Kane, \& Rees, 2010). This therapeutic approach is effective in the treatment of depression, but it can also enhance well-being in non-clinical populations. Summing up, recovery does not only entail detaching from work and resting, but also building new resources and engaging in meaningful leisure activities.

In addition to leisure activities, psychological experiences underlying these activities are important for recovery. Sonnentag and Fritz (2007) suggested a framework of four major recovery experiences: psychological detachment from work, relaxation, control, and mastery. Of these experiences, detachment seems to be most consistently associated with positive changes in well-being (for reviews, see Sonnentag \& Fritz, 2015; Wendsche \& Lohmann-Haislah, 2017). Several studies have also demonstrated positive links between relaxation, control, mastery, and well-being (for a meta-analysis, 
see Bennett, Bakker, \& Field, 2018). Newman, Tay and Diener (2014) recently extended the list of important recovery experiences in their DRAMMA model, which aims to explain the relation between leisure activities and subjective well-being. The assumed explanatory mechanisms are detachment, relaxation (labeled “recovery” in the original model), autonomy, mastery, meaning, and affiliation. Detachment refers to mental disengagement from work-related thoughts. Relaxation implies low levels of mental or physical activation and little physical or intellectual effort (Sonnentag \& Fritz, 2007). Autonomy refers to feelings of decision latitude and is one of the basic psychological needs suggested in Self-Determination Theory (Ryan \& Deci, 2000). It resembles control in Sonnentag and Fritz’s (2007) framework but is broader, emphasizing feelings of volition in general instead of merely having control over one’s leisure schedule. Mastery encompasses learning opportunities and challenges resulting in feelings of achievement and competence (Sonnentag \& Fritz, 2007). Meaningful leisure activities are a means by which individuals gain something valuable in their lives (Iwasaki, 2008). Affiliation refers to feelings of belongingness and the fulfillment of people’s innate need for relatedness (Ryan \& Deci, 2000). In the present study, we examined all six DRAMMA experiences in the context of a vacation.

\subsection{Strengthening and prolonging recovery during vacations}

Both shorter and longer vacations have shown beneficial effects on recovery, well-being, and performance (de Bloom, Geurts, \& Kompier, 2012; 2013), but these effects soon fade and occasionally fail to appear at all (de Bloom et al., 2009) . For example, negative incidents, engagement in passive activities (de Bloom et al., 2011), and lack of detachment from work (Kühnel \& Sonnentag, 2011) during a vacation may limit positive vacation effects on well-being. It is also possible that although vacationers benefit from engaging in pleasant recreational activities during the vacation, maintaining such behaviors during daily life is challenging (Smyth et al., 2018). Experiences of detachment and relaxation during the vacation appear to strengthen its positive effects on well-being 
(Fritz \& Sonnentag, 2006). Also, relaxation during leisure time after the vacation may delay the fadeout of vacation effects (Kühnel \& Sonnentag, 2011).

To the best of our knowledge, Holidaily is the first mobile intervention designed to promote recovery during a vacation and to prolong the duration of beneficial vacation effects. Holidaily is designed to promote the previously mentioned DRAMMA recovery experiences (Newman et al., 2014), and is theoretically based on positive psychology interventions (see for example Sin \& Lyubomirsky, 2009) and behavior modification strategies (Mazzucchelli et al., 2010). In the method section and in Appendix 1 we provide a more detailed description of the app. For example, we provide screenshots showing examples of exercises in the app. Previous studies suggest that it is possible to support recovery from work and enhance recovery experiences with interventions such as relaxation techniques, recovery experience training, and promotion of physical activity (for a review, see Verbeek et al., 2018). For instance, a face-to-face group intervention by Hahn et al. (2011) strengthened detachment, relaxation, and control after work, and the effects were still visible four weeks after the intervention. Mindfulness exercises can also enhance detachment after the workday (Michel, Bosch, \& Rexroth, 2014). During the working day, an intervention including park walks and relaxation exercises supported recovery (De Bloom et al., 2017; Sianoja, Syrek, De Bloom, Korpela, \& Kinnunen, 2017).

Our study concerned an occupational e-mental health intervention: the recovery intervention was delivered by mobile technology (i.e., a smartphone application), which supports the smooth and effortless integration of interventions into everyday life. Occupational e-mental health refers to the application of internet- and smartphone-based tools, which aim to improve the well-being of workers (Lehr et al., 2016). Web-based interventions are promising tools in treating various mental health problems (Haug, Nordgreen, Öst, \& Havik, 2012; Königbauer, 2017; Richards \& Richardson, 2012) and in promoting psychological well-being and work effectiveness (for a meta-analysis, see Carolan, 
Harris, \& Cavanagh, 2017), but the empirical evidence for the efficacy of smartphone-based interventions is limited so far (Fiordelli, Diviani, \& Schulz, 2013).

The few existing studies indicate that it may also be possible to utilize web-based tools to implement interventions targeted specifically at supporting recovery from work. In a web-based intervention focusing on teachers' recovery in the evening after work (Ebert et al., 2015), sleep quality and recovery experiences improved, and rumination decreased. Thiart and colleagues (2015) reported that the same intervention decreased the severity of insomnia among employees. An online stress management intervention by Ebert and colleagues (2016) also enhanced detachment from work in the evening and reduced stress, sleeping problems, and worrying among employees with elevated stress symptoms. In the first published study using the same Holidaily app as in the present study, Smyth and colleagues (2018) focused on the importance of user experiences in predicting the effectiveness of the app intervention in a German sample. They found that usability of the app relates to better recovery after the vacation.. Summing up, the results from previous studies suggest that recovery among teachers, our target group, can be supported with web-based tools.

\subsection{Aims of the study}

The main aim of this study was to investigate the effects of a one-week vacation on recovery experiences, well-being, and job performance, and to examine whether it is possible to strengthen these effects and prolong their duration with the help of a smartphone-based intervention. The study included two pre-vacation measurements (T1-T2), one measurement during the vacation (T3) and two post-vacation measurements (T4-T5). Low adherence is a common problem in eHealth interventions (e.g., Carolan et al., 2017). To control for self-selection effects, we investigated whether the participants who used the app more actively differed from non-users or passive users at baseline (T1) in background factors and in the outcomes mentioned above. Secondly, we investigated if there 
was a dose-response relationship in app use (i.e., whether more intensive use of the app resulted in stronger and longer lasting effects). That is, we examined, whether the temporal development of outcomes differed between non-users, passive and active app users. Finally, we conducted a few short interviews to find out more about user experiences.

Summing up, our main hypotheses were:

Hypothesis 1: Teachers report higher recovery experiences, more well-being and better job performance after a vacation than before.

Hypothesis 2: Active use of the Holidaily app strengthens recovery experiences, well-being and job performance.

Hypothesis 3: Active use of the Holidaily app prolongs recovery experiences, well-being and job performance.

In addition, we sought answers to two explorative research questions in order to understand the characteristics of different user groups and obtain feedback on qualitative user experiences:

Question 1: How do non-users, passive, and active app users differ regarding background characteristics (e.g., age, gender, teacher type), recovery experiences, well-being, and job performance at baseline (T1)?

Question 2: How do participants describe their user experiences?

\section{Methods}

\subsection{Participants}

As stated earlier, the participants of this study were teachers and we focused on their one-week winter holiday spent in February-March 2018. We started recruiting them in October 2017 by informing schools in the city of Tampere about the opportunity to take part in the study. In addition, the teachers’ trade union published our advertisement in their magazine and on their social media page twice. The most efficient way to recruit participants was social media (84 registrations). All in all, 100 teachers 
from all over Finland registered to participate. However, only 79 of them responded to the first weekly questionnaire in February 2018 and actually took part in the study. Background information of the participants in three app use groups is presented in Table 1.

\subsection{The smartphone-based recovery intervention}

We conducted our recovery intervention with the help of a smartphone app called Holidaily (available for iOS and Android). It was developed at Leuphana University in Germany (Lehr, de Bloom, \& Syrek, 2016-2018), translated and adapted to the Finnish context as part of this research project. The general aim of the app is to motivate users to integrate recovery-promoting activities and experiences in their vacations and daily lives. The app includes short daily exercises, called "Dailies” (“Daily”), which are designed to promote the six recovery experiences suggested by the DRAMMA model (Newman et al., 2014; see Appendix 1 for examples).

The "Daily" exercises are based on three approaches. The first approach relates to positive psychology interventions, which are treatment methods or self-administered activities aimed at cultivating positive feelings, behaviors, and cognitions (Sin \& Lyubomirsky, 2009). Two reviews suggest that these interventions can enhance psychological well-being (Bolier et al., 2013; Meyers, van Woerkom, \& Bakker, 2012). According to Lyubomirsky and Layous (2013), the mechanisms behind these effects are need satisfaction and the elicitation of positive emotions, thoughts, and behaviors. Gander, Proyer, and Ruch (2017) suggest that to successfully promote well-being, positive psychology interventions should both increase positive emotions and foster cognitive changes, such as gaining new insights. The second approach utilizes behavioral activation and modification and entails prompts for specific activities that have a positive influence on mental health (Mazzucchelli et al., 2010). "Dailies” using behavior modification combine a variety of techniques such as meditation, cognitive restructuring, and relaxation exercises, which have also been used in stress 
management interventions (Richardson \& Rothstein, 2008). Thirdly, gamification elements (e.g., avatars and collecting "recovery points") are utilized to motivate users to use the app actively and adopt recovery behavior changes. Evidence so far suggests that gamification can have a positive impact on well-being-related interventions (Johnson et al., 2016), but it has not yet been used widely in stress management apps (Hoffmann, Christmann, \& Bleser, 2017).

When the users start using Holidaily, they enter practical information about their upcoming vacation (i.e., dates and destination) in order to receive the "Daily" suggestions timed according to their individual vacation planning. Each "Daily” description also includes the targeted DRAMMA needs and the effort required to complete this specific "Daily". In the following weeks, the app suggests three different "Dailies” every day. Users select one "Daily” per day, can save interesting "Dailies” to be completed later, and can also create their own "Dailies”. After completing each "Daily”, users are asked to rate to which extent it helped them experience DRAMMA dimensions and to upload their own pictures and notes related to the completion of the "Daily". This personal diary can be accessed and reviewed by the user at any time. Users are also encouraged to rate their daily wellbeing with a few short questions in the app each day. Users can choose to receive push notifications to remind them about the app use. The app is self-guided but includes an instruction video in Finnish and a short description of the main features under the "Help" function. Screenshots of the main functionalities of the app can be found in Appendix 1.

\subsection{Study design}

One week before the study started, we sent the participants an email including practical information about the study, links to download the app, and individual registration codes for the app. The study started on the Wednesday 11/2 weeks before the scheduled beginning of the vacation and ended on the Wednesday $1 \frac{1}{2}$ weeks after the end of the vacation. The participants were instructed to use the app 
every day (i.e., complete one "Daily" exercise per day and rate well-being and recovery with a few short questions) or as often as possible throughout the four-week period. In addition to the app use, the study included five electronic questionnaires sent via email at noon (see Figure 1). Participants were instructed to complete the questionnaires in the evening before going to sleep, but the majority did not follow these instructions: average time for completing the questionnaires ranged between 14:24 and 16:02 in the afternoon (many answered only the following morning). On the next day, we also sent a reminder email for those who had not yet completed the questionnaire. All questionnaires were sent on Wednesdays, except the second questionnaire, which was sent on the last working day (Friday) before the vacation. Wednesdays were chosen because they may best represent an average weekday in terms of well-being and recovery: on Mondays, the beneficial effects of weekend respite may still affect employees' well-being, or employees may already be anticipating the demands of the upcoming week (Rook \& Zijlstra, 2006). Likewise, towards the end of the working week, employees’ well-being may improve in anticipation of the weekend (Hülsheger et al., 2014;). However, the week before the vacation may be particularly stressful due to heavy workload: for example, decline in wellbeing shortly before a vacation occurred in the study by Nawijn, de Bloom, and Geurts (2013). Therefore, the second questionnaire was sent on the last working day before starting the vacation. Along with the app use and the questionnaires, we conducted nine semi-structured qualitative interviews via phone or email after the study period to find out more about participants' experiences of app use.

\subsection{Measures}

The weekly questionnaires included the following measures:

Recovery experiences were measured using adaptations of validated scales such as the Recovery Experience Questionnaire (REQ, Sonnentag \& Fritz, 2007) and other existing scales (see Table 2 for details). 
Well-being was measured using scales for positive and negative affect based on PANAS, sleep quality, and need for recovery. Affect was measured with items including four positive (calm/relaxed, enthusiastic, energetic/vigorous, alive/vital) and four negative emotions (fatigued/tired, irritated, tense, gloomy).

Job performance was measured with single items for task performance and concentration capacity, and a scale for creativity at work. See Table 2 for details.

\subsection{Statistical analyses}

We used multiple imputations to handle missing data, since only 39 participants responded to all five weekly questionnaires $(=49 \%$ of the initial sample). Across all outcome variables, the mean percentage of missing data was $28 \%$. The percentage of missing data varied between $4 \%-42 \%$. At T1, there were least missing values (up to 5\%), whereas the amount of missing values increased at later time points (up to $42 \%$ at T5). Multiple imputation techniques are recommended as they provide the best estimate for missing values (Schafer \& Graham, 2002). We used a Markov Chain Monte Carlo multivariate imputation algorithm, using the missing data module in SPSS v. 24, with 100 estimations per missing value. These estimations were aggregated to a single value that was used in all further analyses.

We categorized participants into three groups based on their Holidaily app use (i.e., how many “Daily" exercises they actually completed): non-users, who did not complete any "Dailies $(n=51)$, passive users, who completed 1-4 "Dailies” ( $n=18)$, and active users, who completed more than 4 “Dailies” ( $n=10)$. The number of completed "Dailies” was retrieved from the data provided by the app. The categorization between passive and active was made based on the median $(M d n=4)$ of 
completed "Dailies" among app users. Since most participants did not use the app despite the instructions, we also compared the two actual app use groups to the non-users. To investigate if there were between-group differences in background characteristics and outcomes at baseline (T1), we conducted ANOVAs for continuous variables and chi-squared tests for categorical variables (Table 1).

To test whether the beneficial vacation effects persisted (H1), were strengthened (H2) or prolonged (H3) by app use, we conducted multivariate analyses (MANOVA) for repeated measures. We used the three app use groups as between-subject variable and time as a repeated measure. In addition to group and time effects, we paid special attention to group $\times$ time interaction effects to investigate whether, as expected, the temporal development of outcomes differed between groups. All in all, we conducted two MANOVAs. To the first model, we added all outcome variables measured at all five time points: six DRAMMA recovery experiences, positive and negative affect, and sleep quality. Outcomes examined at only four time points (excluding T3, the vacation week) - task performance, concentration capacity, need for recovery, and creativity at work - were included in the second model. When samples are small, interaction effects are not necessarily detected. Therefore, and also because we were testing a new intervention, we also analyzed the within-subject effects in three user groups separately with MANOVA for repeated measures. This way we also examined whether active app use strengthened vacation effects (T1 vs. T3) or prolonged their duration (T1 vs. T4 and T1 vs. T5). Bonferroni corrections were used in all MANOVAs to reduce the chances of family-wise error. All statistical analyses were conducted in SPSS 24 software.

\section{Results}

\subsection{Descriptive results regarding app use}

Although all participants were instructed to use the app on a daily basis, 51 of them did not record any "Daily” exercises in the app (35 participants did not download the app at all). In the whole sample 
(including non-users), the mean of completed "Dailies" was 4.49. There was considerable variation (range 0-192, $S D=22.00, M d n=0$ ), which means that the distribution of this variable was very skewed. Among those participants who completed at least one "Daily” (i.e., used the app), the median of completed "Dailies" was 4 . We used this number as a cutoff point to divide the users into active and passive users: active users completed more than four "Dailies", while passive users completed four or fewer "Dailies”. It is important to note that even most of the "active” users only used the app occasionally: only five participants completed more than 10 "Dailies".

\subsection{Differences between non-users, passive, and active app users in background characteristics,} recovery experiences, well-being, and job performance before the vacation (T1)

No statistically significant differences were found in background characteristics between the three app use groups. Nor did the app use groups differ significantly in recovery experiences, well-being, and performance-related variables measured at baseline (T1).

3.3. Development of recovery experiences, well-being, and job performance in non-users, passive, and active app users between T1-T5

The results of the repeated measures MANOVAs including all participants are presented in Table 3 (recovery experiences), Table 4 (well-being outcomes), and Table 5 (performance-related outcomes). Figures 2 and 3 show the development of the outcomes within the three user groups whenever the time effect was significant.

Time effects. When testing together the temporal effects on recovery experiences and well-being outcomes (except for need for recovery) with MANOVA for repeated measures, the time effect was significant $(F(36,1196)=5.504, p<.001)$. All recovery experiences except mastery showed a significant vacation effect: they were rated higher during the vacation (T3; $p<.05-.001)$ than at all 
other time points. In similar vein positive affect $(p<.001)$ and sleep quality $(p<.001)$ were rated significantly higher and negative affect lower $(p<.001)$ during the vacation (T3) than at all other time points. In addition, negative affect was rated lower at T4 than at baseline (T1) $(p=.042)$. When testing the temporal effects on performance measures and need for recovery with MANOVA, the time effect was significant $(F(12,681)=3.345, p=.001)$. Task performance or concentration capacity did not change over time. Concerning creativity, the time effect was statistically significant. Pairwise comparisons suggest that creativity was somewhat ( $p=.053$; marginally significant) lower after the vacation (T4) than at baseline (T1). Need for recovery was rated significantly lower a few days after the vacation $(\mathrm{T} 4)$ than at baseline $(\mathrm{T} 1 ; p=.020)$. Also, need for recovery was rated lower one and a half weeks after the vacation (T5) than at baseline (T1; $p=.001$ ) or on the last working day before the vacation $(\mathrm{T} 2 ; p=.002)$.

Group effects. The results did not show statistically significant group effects between non-users, active and passive app users.

Interaction effects. No interaction effects were detected in the two MANOVAs for repeated measures, except for one statistically significant time $\times$ group interaction concerned creativity at work (see Table 5 and Figure 3). Before the vacation, active users rated their creativity lower than did non-users and passive users, but after the vacation the ratings of active users reached the same level as those of passive users, whereas the ratings of non-users decreased from T1 and T2 to T4.

The repeated measures MANOVAs in user groups separately revealed that the user groups did not differ in the development between $\mathrm{T} 1$ and T3. This indicates that app use did not strengthen the beneficial vacation effects on those outcomes measured at T3, i.e., recovery experiences and wellbeing outcomes (except for need for recovery). 
At $\mathrm{T} 4$, active users reported significantly lower negative affect than at $\mathrm{T} 1(F(4,36)=6.522, p=$ .039), but among non-users or passive users this difference was not significant. Among non-users, need for recovery decreased from $\mathrm{T} 1$ to $\mathrm{T} 4$ and $\mathrm{T} 5(F(3,150)=8.194, p=.037$ when comparing $\mathrm{T} 1$ \& T4 and $F(3,150)=8.194, p=.024$ when comparing T1 \& T5). Passive users showed no significant change in need for recovery over time. Among active users, need for recovery decreased from T1 to $\mathrm{T} 5(F(3,27)=4.355, p=.031)$. Non-users rated their creativity at work lower at T4 than at $\mathrm{T} 1(F$ $(3,150)=8.072, p<.001)$ whereas among passive or active users there was no significant difference (indicating that creativity remained stable, or slightly increased among active users, which can be seen in Figure 3).

All in all, the results partially support hypothesis 1 , expecting beneficial vacation effects: the vacation effects were found on five recovery experiences (detachment, relaxation, autonomy, meaning, affiliation) and well-being (positive and negative affect, sleep quality, need for recovery). Hypothesis 2, expecting that app use would strengthen the beneficial vacation effects, was not supported. Hypothesis 3, expecting that app use would prolong the vacation effects, gained partial support: active app use prolonged the duration of beneficial vacation effects on negative affect. Active use also seemed to protect against a decrease in creativity after the vacation. 


\subsection{User experiences}

Participants had an opportunity to give written feedback in all five weekly questionnaires and also to contact the researchers by email. Written feedback related to the app mostly concerned technical problems (12 mentions), such as slowness or difficulties logging in. Of the nine participants we interviewed after the study, two had completed more than four "Daily" exercises (one as much as 192, being the most active app user in the sample), six had completed four or fewer "Dailies", and one had not used the app at all. Of the interviewees, around a half (5/9, 2 active and 3 passive users) stated that the basic idea of the app was good and that it helped them to pay more attention to wellbeing. Most interviewees (6/9, 1 active and 5 passive users) reported challenges related to recovery (e.g. ruminating about work in the evening hours, sleeping problems), which was an important motive for participating in the study. Opinions were divided on the "Daily" exercises. Two interviewees (1 active and 1 passive user) enjoyed them and said they were useful and varied. Four interviewees (passive users) statedthat there was too much similarity among the "Dailies”. Six interviewees (2 active and 4 passive users) said that the app was easy to use, but three of them (passive users) also reported some technical problems due to which app use was decreased and sometimes even experienced as stressful. Four interviewees ( 1 active and 3 passive users) stated that self-ratings of well-being in the app helped them to reflect on their daily well-being.

\section{Discussion}

The aim of this study was to investigate the effects of a one-week vacation on recovery experiences, well-being, and job performance, and to ascertain if it is possible to strengthen these effects and prolong their duration by means of active use of a smartphone app. We also investigated if there were differences between non-users, passive users, and active users at baseline to learn more about possible factors behind inactive app use, and conducted short qualitative interviews focusing on user experiences. 


\subsection{Main results}

Our results show beneficial vacation effects in terms of recovery experiences and well-being. However, as in previous studies (e.g., de Bloom et al., 2009; Reizer \& Mey-Raz, 2018) these effects were short-lived. All recovery experiences except mastery were rated higher during the vacation than before and after. The teachers also experienced more positive affect and less negative affect during the vacation than before or after. Sleep quality improved during and need for recovery decreased after vacation. Creativity at work was rated lower a few days after the vacation than at baseline (except among active app users) but increased slightly above baseline 1.5 weeks after the vacation, matching previous findings demonstrating links between vacationing and cognitive flexibility, a core aspect of creativity (De Bloom et al., 2014).

The results also suggest that although the use of the Holidaily app did not strengthen positive vacation effects, active use may have prolonged the duration of some beneficial vacation effects. Among active app users, creativity at work increased slightly from baseline to after the vacation, whereas among non-users it decreased and among passive users it decreased a few days after the vacation but increased again 1.5 weeks after the vacation. The fading of beneficial vacation effects on negative affect seems to have been slower among active users: a few days after the vacation, they still reported lower levels of negative affect than at baseline, which was not the case among non-users or passive users.

When comparing the three app use groups in background characteristics and outcome variables at baseline, we found no significant differences. In the short qualitative interviews, several participants described challenges related to recovery from work, and reported that these challenges motivated them to participate in the study and use the app. To the best of our knowledge, Holidaily is the first app designed specifically to promote recovery from work. Based on the feedback from users in 
Germany (see Smyth et al., 2018) and results from this study, a second version of the app is currently under development (Holidaily 2.0).

\subsection{Contributions, limitations, and practical implications}

Our results imply that actively engaging in intentional, recovery-promoting activities presented in a gamified app may support employees' recovery, well-being, and performance. However, the effects were marginal, and only few of them were statistically significant. Our results yield limited evidence about the effectiveness of the app because most participants used the app only occasionally and we had no randomized control group. Also, the cut-off point between "passive” and “active” users was arbitrary, although based on the median of completed "Daily" exercises among users. Since most of the participants did not follow our instructions to use the app actively, we were able to compare nonusers to passive and more active app users in terms of the temporal development of the outcomes. Thus, the non-user group can serve as a proxy for a control group. No statistically significant betweengroup differences in background characteristics or outcome variables at baseline (see Results section 3.3. for more details) were found, which means that the groups were comparable.

Our study constitutes an important advance in the burgeoning field of occupational e-mental health. Most studies so far in this field have utilized internet-based interventions instead of smartphones (Lehr et al., 2016). Smartphone-based technology is cost-effective and accessible, and it can facilitate incorporating interventions into daily life: most people have their phones on them 24/7. Mobile interventions are also flexible: for example, in our app people were always able to choose from several different exercises or come up with own ideas for "Dailies". This may help to preserve a sense of autonomy over one's leisure time. The wide range of activities also makes an intervention accessible to many different populations, including people who are not able to engage in certain activities (e.g. in physical activities due to illness or disability). 
Our study also demonstrated that mobile interventions mean: “easy in, easy out”. The benefit of easy accessibility for large groups of people means that mobile apps have a good reach, but dropout and low adherence are a problem. In a meta-analysis by Carolan and colleagues (2017), the mean reported completion of web-based interventions delivered at the workplace was only 45\%. People easily become excited about the use of apps and commit to taking part in interventions. We explicitly recruited participants for a “mobile recovery intervention using a smartphone app”. Still, more than half of the participants did not complete any exercises in the app, although they did continue to complete our questionnaires. In addition to the number of completed "Dailies”, we retrieved the total number of liked, planned, and completed “Dailies” from the app data. We assumed that it might be possible that participants did not always remember to record the "Dailies" in the app even though they had completed the recommended exercises. The mean of liked, planned, and completed "Dailies” together was indeed higher $(M=22.05)$, but again the deviation was very wide (range $0-411, S D=$ 67.35, $M d n=6$ ), and only a few participants were very active. This shows that getting people to actually use intervention apps is extremely challenging. In addition, “active” app use in our study means being active at a very low level. On the other hand, our results show that even a small amount of app use may make a positive difference: although most "active” users only used the app occasionally, a few differences between active users and non-users or passive users were found. Applying a relatively conservative analysis strategy using Bonferroni corrections in all MANOVAs may also have limited the occurrence of statistically significant results. It was not our aim to motivate people to constantly use their smartphones while on vacation, and therefore it is promising to see that even quite infrequent app use may be beneficial. Also, highly stressed individuals may not have time or energy for intense app use, although they probably have the greatest need to change their habits with a view to recovery. 
One possible reason for not engaging in the intervention or only using the app infrequently is lack of guidance. Earlier studies suggest that the provision of guidance increases engagement in occupational e-mental health interventions (Carolan et al., 2017). Meta-analyses of e-mental health interventions targeted at alleviating stress and depression also suggest that guidance improves both adherence and effectiveness (Heber et al., 2017; Richards \& Richardson, 2012). However, the provision of human support limits the large-scale dissemination of these interventions. We provided instructions for the app by email and our app also includes an instruction video which automatically shows when people open the app for the first time. Nevertheless, it seems that this did not suffice to engage all participants in using the app. Personal guidance by a research assistant would probably have increased app use, but unfortunately our means were too limited to realize such personal contact. Besides the low adherence in app use, most of the participants did not follow the instructions concerning weekly questionnaires: only 10-29\% completed the questionnaires in the evening, as instructed. Since most items concerned the week so far, this is probably not very problematic. Future studies could make use of in-company (or in-school) group training sessions to guide participants in using the app and committing themselves to the intervention. Our Holidaily app had an optional reminder functionality (sending participants one reminder a day), but unfortunately it did not yet work properly due to technical problems.

Once participants started using the app, technical problems discouraged some of them from using it actively. This highlights the importance of user experience in smartphone-based interventions. Smyth and colleagues (2018) showed that the use of Holidaily was related to improvements in recovery experiences after the vacation and that good user experience enhanced these effects. It should also be considered that although smartphone apps are promising tools in promoting well-being, they may not work for everyone. They are probably attractive to people who already enjoy using apps, but on the other hand they may cause stress for those who are not comfortable using mobile technology. Our 
target group, teachers (especially older ones), often experience stress related to ICT use at work (e.g., Syvänen, Mäkiniemi, Syrjä, Heikkilä-Tammi, \& Viteli, 2016), and it is possible that at worst, smartphone-based interventions could be another source of technostress. In addition, smartphone use may sometimes hamper recovery because smartphones blur the boundaries between work and home domains and allow constant access to work-related activities, which prevents detachment from work (e.g., Van Laethem, van Vianen, \& Derks, 2018). Therefore, it may be problematic to set boundaries between beneficial and detrimental smartphone use during leisure time. Smartphone use is pervasive in today's society. It is important for research to take this fact into account and aim to promote using smartphones in a way that may be beneficial to well-being. The effectiveness of well-being and recovery apps needs further research in larger and more diverse samples to identify groups of people most likely to benefit from e-mental health approaches.

Many occupational groups, like the teachers in our study, experience high job demands, stress, and difficulties to recover during evenings and weekends (e.g., Garrick et al., 2018; Skaalvik \& Skaalvik, 2015; 2017). Accordingly, interventions supporting their recovery from work are undoubtedly needed. Nonetheless, it is often teachers' working environment that causes job stress and burnout (e.g., Skaalvik \& Skaalvik, 2015; 2017). This means that occupational well-being cannot be solely under the responsibility of the individual employee. Recovery interventions focusing on individuals have only limited means for preventing the serious consequences of accumulating stress.

\subsection{Suggestions for future research}

The findings of this study suggest several avenues for future research. Our theoretical framework, the DRAMMA model (Newman et al., 2014), is relatively new and more research is needed to investigate how the six recovery experiences jointly affect well-being and job performance (see e.g., Sheldon \& Niemiec, 2006). Also, randomized controlled trials would provide more reliable information about 
the effectiveness of the app. All in all, applications of occupational e-mental health deserve further research as the whole research field is still relatively new. For instance, researchers could examine how adding social media elements to internet- or smartphone-based interventions would impact their effectiveness. It is also important to identify individuals who would benefit most from smartphonebased interventions, for example, people who already enjoy using apps and are comfortable with mobile technology. A few of our participants reported that they were not "app persons” and found using new applications stressful. Thus, smartphone-based interventions are presumably not ideal for them. Previous studies show that prior exposure to online services and confidence in using technology predict the intention to use e-mental health services (e.g., March et al., 2018; Mehrotra \& Tripathi, 2018). Researchers should pay attention to recruitment strategies and to motivating participants. In addition, it could be worth investigating how to help people find evidence-based smartphone apps among the wide selection of well-being apps available. Although the number of commercial wellbeing apps in app stores is enormous, most of them are not evidence-based (Firth et al., 2017) and sometimes offer poor quality of information, engagement, and functionality (Donker et al., 2013). It may moreover be difficult for users to identify which apps are evidence-based.

\subsection{Conclusions}

The results of this study suggest that with the help of a gamified smartphone app providing daily suggestions for recovery activities it may be possible to prolong the beneficial effects of vacations on well-being and job performance. In the future, the Holidaily app could be available to all those interested in paying more attention to recovery during a vacation. The exercises in the app can potentially also be adapted to promote daily recovery during weekends, evenings, and breaks during the working day. Building new resources and possibly forming new, healthy habits with the help of recovery exercises could in the long run help employees to recover better in their daily lives. Further 
research on larger and more diverse samples is needed to accumulate more evidence for the effectiveness of mobile interventions targeted at enhancing recovery from work. 
Table 1. Participants' background information in three app use groups

\begin{tabular}{|c|c|c|c|}
\hline & Non-users $(n=51)$ & Passive users $(n=18)$ & Active users $(n=10)$ \\
\hline & $n(\%)$ & $n(\%)$ & $n(\%)$ \\
\hline $\begin{array}{l}\text { Completed all } 5 \\
\text { questionnaires }\end{array}$ & $20(39)$ & $13(72)$ & $6(60)$ \\
\hline \multicolumn{4}{|l|}{ Gender } \\
\hline Female & $46(96)$ & $18(100)$ & $8(80)$ \\
\hline Male & $2(4)$ & 0 & $2(20)$ \\
\hline \multicolumn{4}{|l|}{ Job title } \\
\hline Class teachers & $17(36)$ & 7 (39) & $5(50)$ \\
\hline Subject teachers & $19(40)$ & 7 (39) & $5(50)$ \\
\hline Other & $11(24)$ & $4(22)$ & 0 \\
\hline Full-time job & $47(92)$ & $17(94)$ & $9(90)$ \\
\hline \multicolumn{4}{|l|}{ Workplace } \\
\hline $\begin{array}{l}\text { Comprehensive } \\
\text { school }\end{array}$ & $40(83)$ & $16(89)$ & $9(90)$ \\
\hline High school & $5(10)$ & $1(6)$ & $1(10)$ \\
\hline $\begin{array}{l}\text { Both high school and } \\
\text { comprehensive school }\end{array}$ & $2(4)$ & 0 & 0 \\
\hline Other & $1(2)$ & $1(6)$ & 0 \\
\hline \multicolumn{4}{|l|}{ Vacation type } \\
\hline Staying home & $20(42)$ & $6(33)$ & $6(60)$ \\
\hline Domestic travel & $21(44)$ & $10(56)$ & $4(40)$ \\
\hline \multirow[t]{2}{*}{ International travel } & $7(15)$ & $2(11)$ & 0 \\
\hline & $M(S D)$ & $M(S D)$ & $M(S D)$ \\
\hline Mean age in years & $44(9.61)$ & $45(8.37)$ & $44(10.1)$ \\
\hline $\begin{array}{l}\text { Mean working hours } \\
\text { per week }\end{array}$ & 39 (6.33) & $40(8.35)$ & $37(3.00)$ \\
\hline
\end{tabular}


Table 2. Measures in weekly questionnaires

\begin{tabular}{|c|c|c|c|c|c|}
\hline Measure & Range & $\begin{array}{l}\text { Number of } \\
\text { items / } \alpha\end{array}$ & $\begin{array}{l}\text { Time } \\
\text { point }\end{array}$ & Example item & Reference \\
\hline $\begin{array}{l}\text { Recovery } \\
\text { experiences }\end{array}$ & $\begin{array}{l}1 \text { (totally disagree) }-5 \\
\text { (totally agree) }\end{array}$ & & $1-5$ & & \\
\hline Detachment & & $\begin{array}{l}3 \\
\alpha=0.77-0.87\end{array}$ & & "I forgot about work" & Sonnentag \& Fritz, 2007 \\
\hline Relaxation & & $\begin{array}{l}4 \\
\alpha=0.83-0.87\end{array}$ & & "I kicked back and relaxed” & $\begin{array}{l}\text { Sonnentag \& Fritz, } 2007 \\
\text { + one item developed for the study ("I felt } \\
\text { at ease and enjoyed what I was doing") }\end{array}$ \\
\hline Autonomy & & $\begin{array}{l}4 \\
\alpha=0.74-0.87\end{array}$ & & "I determined for myself how I would spend my time" & $\begin{array}{l}\text { Sonnentag \& Fritz, } 2007 \\
\text { Chen et al., } 2015\end{array}$ \\
\hline Mastery & & $\begin{array}{l}5 \\
\alpha=0.79-0.84\end{array}$ & & "I did something to broaden my horizons" & $\begin{array}{l}\text { van den Broeck et al., } 2010 \\
\text { Sonnentag \& Fritz, } 2007\end{array}$ \\
\hline Meaning & & $\begin{array}{l}3 \\
\alpha=0.65-0.88\end{array}$ & & "I spent my time in a meaningful way" & $\begin{array}{l}\text { adapted from Butler \& Kern, } 2016 \\
\text { Schulenberg, Schnetzer, \& Buchanan, } \\
2010\end{array}$ \\
\hline Affiliation & & $\begin{array}{l}3 \\
\alpha=0.74-0.84\end{array}$ & & "I felt loved and cared about" & $\begin{array}{l}\text { La Guardia et al., } 2000 \\
\text { van den Broeck et al., } 2010 \\
\text { Chen et al., } 2015\end{array}$ \\
\hline \multicolumn{6}{|l|}{ Well-being } \\
\hline Positive affect & $\begin{array}{l}1 \text { (not at all) }-7 \text { (very } \\
\text { much) }\end{array}$ & $\begin{array}{l}4 \\
\alpha=0.80-0.93\end{array}$ & $1-5$ & calm/relaxed & $\begin{array}{l}\text { Warr, } 1990 \\
\text { Watson \& Clark, } 1994\end{array}$ \\
\hline Negative affect & $\begin{array}{l}1 \text { (not at all) }-7 \text { (very } \\
\text { much) }\end{array}$ & $\begin{array}{l}4 \\
\alpha=0.78-0.86\end{array}$ & $1-5$ & fatigued/tired & Ryan \& Frederick, 1997 \\
\hline Sleep quality & $\begin{array}{l}1 \text { (very poorly) }-5 \text { (very } \\
\text { well) }\end{array}$ & 1 & $1-5$ & "How have you slept during this week?” & Åkerstedt et al., 1994 \\
\hline Need for recovery & $\begin{array}{l}1 \text { (totally disagree) }-5 \\
\text { (totally agree) }\end{array}$ & $\begin{array}{l}4 \\
\alpha=0.71-0.87\end{array}$ & $1,2,4,5$ & $\begin{array}{l}\text { "When I got home from work, I needed to be left in peace } \\
\text { for a while" }\end{array}$ & $\begin{array}{l}\text { Van Veldhoven \& Broersen, } 2003 \\
\text { Van Veldhoven, Prins, Van der Laken, \& } \\
\text { Dijkstram, } 2015\end{array}$ \\
\hline \multicolumn{6}{|l|}{ Job performance } \\
\hline $\begin{array}{l}\text { Concentration } \\
\text { capacity }\end{array}$ & $\begin{array}{l}1 \text { (not at all) }-7 \text { (very } \\
\text { much) }\end{array}$ & 1 & $1,2,4,5$ & "I felt that today my concentration capacity was good" & $\begin{array}{l}\text { adapted from Van Veldhoven \& Broersen, } \\
2003\end{array}$ \\
\hline Task performance & $0-10$ & 1 & $1,2,4,5$ & $\begin{array}{l}\text { "How would you rate your work performance this week on } \\
\text { a scale from } 0 \text { to } 10 \text {, where } 0 \text { is the worst job performance } \\
\text { anyone could have at your job and } 10 \text { is the performance } \\
\text { of a top worker?" }\end{array}$ & Kessler et al., 2003. \\
\hline Creativity at work & 1 (never) - 5 (always) & $\begin{array}{l}4 \\
\alpha=0.88-0.93\end{array}$ & $1,2,4,5$ & "I came up with creative solutions to problems at work" & $\begin{array}{l}\text { Jaussi, Randel, \& Dionne, } 2007 \\
\text { Tierney, Farmer, \& Graen, } 1999 \\
\text { George \& Zhou, } 2001\end{array}$ \\
\hline
\end{tabular}


Table 3. Results of repeated measures MANOVAs for effects across time, between groups (non-users, passive and active users), and for time $\times$ group interactions on recovery experiences.

\begin{tabular}{|c|c|c|c|c|}
\hline 1) Non-users $(n=51)$ & 2) Passive users $(n=18)$ & 3) Active users $(n=10)$ & $\begin{array}{l}\text { Group } \\
\text { effect }\end{array}$ & Group \\
\hline
\end{tabular}

\begin{tabular}{|c|c|c|c|c|c|c|c|c|c|c|c|c|c|c|c|c|c|c|}
\hline $\begin{array}{l}\text { Recovery } \\
\text { experiences }\end{array}$ & $\mathrm{T} 1$ & $\mathrm{~T} 2$ & T3 & $\mathrm{T} 4$ & T5 & T1 & $\mathrm{T} 2$ & T3 & $\mathrm{T} 4$ & T5 & $\mathrm{T} 1$ & $\mathrm{~T} 2$ & T3 & $\mathrm{T} 4$ & T5 & & & \\
\hline & $\begin{array}{l}M \\
(S D)\end{array}$ & $\begin{array}{l}M \\
(S D)\end{array}$ & $\begin{array}{l}M \\
(S D)\end{array}$ & $\begin{array}{l}M \\
(S D)\end{array}$ & $\begin{array}{l}M \\
(S D)\end{array}$ & $\begin{array}{l}M \\
(S D)\end{array}$ & $\begin{array}{l}M \\
(S D)\end{array}$ & $\begin{array}{l}M \\
(S D)\end{array}$ & $\begin{array}{l}M \\
(S D)\end{array}$ & $\begin{array}{l}M \\
(S D)\end{array}$ & $\begin{array}{l}M \\
(S D)\end{array}$ & $\begin{array}{l}M \\
(S D)\end{array}$ & $\begin{array}{l}M \\
(S D)\end{array}$ & $\begin{array}{l}M \\
(S D)\end{array}$ & $\begin{array}{l}M \\
(S D)\end{array}$ & $\begin{array}{l}F, p, \\
\left(\eta p^{2}\right)\end{array}$ & $\begin{array}{l}F, p, \\
\left(\eta p^{2}\right)\end{array}$ & $\begin{array}{l}F, p, \\
\left(\eta p^{2}\right)\end{array}$ \\
\hline Detachment & $\begin{array}{l}2.33 \\
(1.00)\end{array}$ & $\begin{array}{l}2.20 \\
(0.73)\end{array}$ & $\begin{array}{l}3.49 \\
(0.87)\end{array}$ & $\begin{array}{l}2.20 \\
(0.65)\end{array}$ & $\begin{array}{l}2.23 \\
(0.66)\end{array}$ & $\begin{array}{l}2.39 \\
(1.07)\end{array}$ & $\begin{array}{l}2.41 \\
(0.92)\end{array}$ & $\begin{array}{l}3.34 \\
(0.66)\end{array}$ & $\begin{array}{l}2.03 \\
(0.72)\end{array}$ & $\begin{array}{l}2.17 \\
(0.69)\end{array}$ & $\begin{array}{l}2.20 \\
(1.00)\end{array}$ & $\begin{array}{l}2.00 \\
(0.82)\end{array}$ & $\begin{array}{l}3.41 \\
(1.22)\end{array}$ & $\begin{array}{l}2.62 \\
(1.24)\end{array}$ & $\begin{array}{l}2.74 \\
(0.79)\end{array}$ & ns & $\begin{array}{l}26.70, p \\
<.001 \\
(0.26)\end{array}$ & ns \\
\hline Relaxation & $\begin{array}{l}3.13 \\
(1.06)\end{array}$ & $\begin{array}{l}2.94 \\
(0.84)\end{array}$ & $\begin{array}{l}4.18 \\
(0.70)\end{array}$ & $\begin{array}{l}3.09 \\
(0.72)\end{array}$ & $\begin{array}{l}2.96 \\
(0.71)\end{array}$ & $\begin{array}{l}2.99 \\
(0.75)\end{array}$ & $\begin{array}{l}2.89 \\
(0.83)\end{array}$ & $\begin{array}{l}4.26 \\
(0.49)\end{array}$ & $\begin{array}{l}2.69 \\
(0.70)\end{array}$ & $\begin{array}{l}2.95 \\
(0.70)\end{array}$ & $\begin{array}{l}3.10 \\
(0.89)\end{array}$ & $\begin{array}{l}2.89 \\
(1.01)\end{array}$ & $\begin{array}{l}4.40 \\
(0.45)\end{array}$ & $\begin{array}{l}3.21 \\
(0.69)\end{array}$ & $\begin{array}{l}3.44 \\
(0.44)\end{array}$ & ns & $\begin{array}{l}38.20, p \\
<.001 \\
(0.34)\end{array}$ & ns \\
\hline Autonomy & $\begin{array}{l}3.34 \\
(0.98)\end{array}$ & $\begin{array}{l}3.07 \\
(0.64)\end{array}$ & $\begin{array}{l}4.08 \\
(0.68)\end{array}$ & $\begin{array}{l}3.29 \\
(0.71)\end{array}$ & $\begin{array}{l}3.00 \\
(0.90)\end{array}$ & $\begin{array}{l}3.31 \\
(0.76)\end{array}$ & $\begin{array}{l}3.21 \\
(0.55)\end{array}$ & $\begin{array}{l}4.16 \\
(0.68)\end{array}$ & $\begin{array}{l}3.14 \\
(0.70)\end{array}$ & $\begin{array}{l}3.00 \\
(0.90)\end{array}$ & $\begin{array}{l}3.40 \\
(0.87)\end{array}$ & $\begin{array}{l}3.19 \\
(0.93)\end{array}$ & $\begin{array}{l}4.48 \\
(0.37)\end{array}$ & $\begin{array}{l}3.52 \\
(0.65)\end{array}$ & $\begin{array}{l}3.49 \\
(0.77)\end{array}$ & ns & $\begin{array}{l}27.75, p \\
<.001 \\
(0.27)\end{array}$ & ns \\
\hline Mastery & $\begin{array}{l}3.46 \\
(0.77)\end{array}$ & $\begin{array}{l}3.41 \\
(0.63)\end{array}$ & $\begin{array}{l}3.27 \\
(0.73)\end{array}$ & $\begin{array}{l}3.25 \\
(0.57)\end{array}$ & $\begin{array}{l}3.21 \\
(0.68)\end{array}$ & $\begin{array}{l}3.34 \\
(0.89)\end{array}$ & $\begin{array}{l}3.33 \\
(0.64)\end{array}$ & $\begin{array}{l}3.17 \\
(0.91)\end{array}$ & $\begin{array}{l}3.47 \\
(0.67)\end{array}$ & $\begin{array}{l}3.32 \\
(0.67)\end{array}$ & $\begin{array}{l}3.24 \\
(1.01)\end{array}$ & $\begin{array}{l}2.93 \\
(1.12)\end{array}$ & $\begin{array}{l}3.51 \\
(1.00)\end{array}$ & $\begin{array}{l}3.25 \\
(0.93)\end{array}$ & $\begin{array}{l}3.33 \\
(0.71)\end{array}$ & ns & ns & ns \\
\hline Meaning & $\begin{array}{l}3.75 \\
(0.87)\end{array}$ & $\begin{array}{l}3.68 \\
(0.59)\end{array}$ & $\begin{array}{l}4.17 \\
(0.68)\end{array}$ & $\begin{array}{l}3.49 \\
(0.68)\end{array}$ & $\begin{array}{l}3.57 \\
(0.61)\end{array}$ & $\begin{array}{l}3.48 \\
(0.99)\end{array}$ & $\begin{array}{l}3.59 \\
(0.72)\end{array}$ & $\begin{array}{l}4.23 \\
(0.62)\end{array}$ & $\begin{array}{l}3.46 \\
(0.90)\end{array}$ & $\begin{array}{l}3.35 \\
(0.87)\end{array}$ & $\begin{array}{l}3.67 \\
(0.72)\end{array}$ & $\begin{array}{l}3.58 \\
(0.63)\end{array}$ & $\begin{array}{l}4.37 \\
(0.51)\end{array}$ & $\begin{array}{l}3.73 \\
(0.87)\end{array}$ & $\begin{array}{l}3.73 \\
(0.42)\end{array}$ & ns & $\begin{array}{l}16.00, p \\
<.001 \\
(0.17)\end{array}$ & ns \\
\hline Affiliation & $\begin{array}{l}3.64 \\
(0.89)\end{array}$ & $\begin{array}{l}3.61 \\
(0.82)\end{array}$ & $\begin{array}{l}3.95 \\
(0.75)\end{array}$ & $\begin{array}{l}3.67 \\
(0.74)\end{array}$ & $\begin{array}{l}3.66 \\
(0.73)\end{array}$ & $\begin{array}{l}3.68 \\
(1.02)\end{array}$ & $\begin{array}{l}3.53 \\
(0.99)\end{array}$ & $\begin{array}{l}4.13 \\
(0.76)\end{array}$ & $\begin{array}{l}3.85 \\
(0.68)\end{array}$ & $\begin{array}{l}3.70 \\
(0.78)\end{array}$ & $\begin{array}{l}3.90 \\
(0.75)\end{array}$ & $\begin{array}{l}3.71 \\
(0.85)\end{array}$ & $\begin{array}{l}4.40 \\
(0.44)\end{array}$ & $\begin{array}{l}3.94 \\
(0.70)\end{array}$ & $\begin{array}{l}3.78 \\
(0.63)\end{array}$ & ns & $\begin{array}{l}7.75, p \\
<.001 \\
(0.09)\end{array}$ & ns \\
\hline
\end{tabular}

Note: degrees of freedom $(4,304)$ on time effects, $(8,304)$ on interactions, and $(2,76)$ on group effects 
Table 4. Results of repeated measures MANOVAs for effects across time, between groups (non-users, passive and active users), and for time $\times$ group interactions on well-being.

\begin{tabular}{|c|c|c|c|c|c|c|c|c|c|c|c|c|c|c|c|c|c|c|}
\hline \multirow[b]{2}{*}{$\begin{array}{l}\text { Well- } \\
\text { being }\end{array}$} & \multirow{2}{*}{ 1) } & \multicolumn{4}{|c|}{ Non-users $(n=51)$} & \multirow{2}{*}{$\begin{array}{rr}\text { 2) } \\
\\
\\
1\end{array}$} & \multicolumn{4}{|c|}{ Passive users $(n=18)$} & \multirow{2}{*}{$\begin{aligned} \text { 3) } \\
\\
\\
1\end{aligned}$} & \multicolumn{4}{|c|}{ Active users $(n=10)$} & \multirow{2}{*}{$\begin{array}{l}\text { Group } \\
\text { effect }\end{array}$} & \multirow{2}{*}{$\begin{array}{l}\text { Time } \\
\text { effect }\end{array}$} & \multirow{2}{*}{$\begin{array}{l}\text { Group } \\
\times \\
\text { time } \\
\text { effect }\end{array}$} \\
\hline & & $\mathrm{T} 2$ & T3 & $\mathrm{T} 4$ & T5 & & $\mathrm{T} 2$ & T3 & $\mathrm{T} 4$ & T5 & & $\mathrm{T} 2$ & T3 & $\mathrm{T} 4$ & T5 & & & \\
\hline & $\begin{array}{l}M \\
(S D)\end{array}$ & $\begin{array}{l}M \\
(S D)\end{array}$ & $\begin{array}{l}M \\
(S D)\end{array}$ & $\begin{array}{l}M \\
(S D)\end{array}$ & $\begin{array}{l}M \\
(S D)\end{array}$ & $\begin{array}{l}M \\
(S D)\end{array}$ & $\begin{array}{l}M \\
(S D)\end{array}$ & $\begin{array}{l}M \\
(S D)\end{array}$ & $\begin{array}{l}M \\
(S D)\end{array}$ & $\begin{array}{l}M \\
(S D)\end{array}$ & $\begin{array}{l}M \\
(S D)\end{array}$ & $\begin{array}{l}M \\
(S D)\end{array}$ & $\begin{array}{l}M \\
(S D)\end{array}$ & $\begin{array}{l}M \\
(S D)\end{array}$ & $\begin{array}{l}M \\
(S D)\end{array}$ & $\begin{array}{l}F, p, \\
\left(\eta p^{2}\right)\end{array}$ & $\begin{array}{l}F, p, \\
\left(\eta p^{2}\right)\end{array}$ & $\begin{array}{l}F, p, \\
\left(\eta p^{2}\right)\end{array}$ \\
\hline $\begin{array}{l}\text { Positive } \\
\text { affect }\end{array}$ & $\begin{array}{l}3.49 \\
(1.20)\end{array}$ & $\begin{array}{l}3.65 \\
(1.09)\end{array}$ & $\begin{array}{l}5.01 \\
(1.18)\end{array}$ & $\begin{array}{l}3.56 \\
(0.87)\end{array}$ & $\begin{array}{l}3.55 \\
(1.08)\end{array}$ & $\begin{array}{l}3.03 \\
(1.16)\end{array}$ & $\begin{array}{l}3.63 \\
(1.28)\end{array}$ & $\begin{array}{l}4.62 \\
(1.03)\end{array}$ & $\begin{array}{l}3.17 \\
(0.85)\end{array}$ & $\begin{array}{l}3.20 \\
(1.04)\end{array}$ & $\begin{array}{l}3.50 \\
(1.42)\end{array}$ & $\begin{array}{l}3.59 \\
(1.61)\end{array}$ & $\begin{array}{l}5.21 \\
(0.96)\end{array}$ & $\begin{array}{l}4.14 \\
(1.37)\end{array}$ & $\begin{array}{l}4.45 \\
(1.08)\end{array}$ & ns & $\begin{array}{l}30.10 \\
p< \\
.001 \\
(0.28)\end{array}$ & ns \\
\hline $\begin{array}{l}\text { Negative } \\
\text { affect }\end{array}$ & $\begin{array}{l}3.74 \\
(1.17)\end{array}$ & $\begin{array}{l}3.59 \\
(1.04)\end{array}$ & $\begin{array}{l}2.33 \\
(1.03)\end{array}$ & $\begin{array}{l}3.34 \\
(1.02)\end{array}$ & $\begin{array}{l}3.41 \\
(0.94)\end{array}$ & $\begin{array}{l}3.64 \\
(1.46)\end{array}$ & $\begin{array}{l}3.68 \\
(1.37)\end{array}$ & $\begin{array}{l}2.53 \\
(1.16)\end{array}$ & $\begin{array}{l}3.58 \\
(1.28)\end{array}$ & $\begin{array}{l}3.73 \\
(1.40)\end{array}$ & $\begin{array}{l}4.48 \\
(1.45)\end{array}$ & $\begin{array}{l}4.22 \\
(1.82)\end{array}$ & $\begin{array}{l}2.58 \\
(1.16)\end{array}$ & $\begin{array}{l}3.50 \\
(1.43)\end{array}$ & $\begin{array}{l}3.49 \\
(1.31)\end{array}$ & ns & $\begin{array}{l}22.42, \\
p< \\
.001 \\
(0.23)\end{array}$ & ns \\
\hline $\begin{array}{l}\text { Sleep } \\
\text { quality }\end{array}$ & $\begin{array}{l}3.18 \\
(1.17)\end{array}$ & $\begin{array}{l}2.89 \\
(0.93)\end{array}$ & $\begin{array}{l}3.93 \\
(0.76)\end{array}$ & $\begin{array}{l}3.17 \\
(0.85)\end{array}$ & $\begin{array}{l}2.94 \\
(0.96)\end{array}$ & $\begin{array}{l}2.94 \\
(1.00)\end{array}$ & $\begin{array}{l}2.91 \\
(1.01)\end{array}$ & $\begin{array}{l}3.71 \\
(0.96)\end{array}$ & $\begin{array}{l}2.84 \\
(1.17)\end{array}$ & $\begin{array}{l}2.85 \\
(0.94)\end{array}$ & $\begin{array}{l}3.00 \\
(0.82)\end{array}$ & $\begin{array}{l}2.84 \\
(1.11)\end{array}$ & $\begin{array}{l}4.22 \\
(0.63)\end{array}$ & $\begin{array}{l}3.61 \\
(1.08)\end{array}$ & $\begin{array}{l}3.61 \\
(0.84)\end{array}$ & ns & $\begin{array}{l}15.34 \\
p< \\
.001 \\
(0.17)\end{array}$ & ns \\
\hline $\begin{array}{l}\text { Need for } \\
\text { recovery }\end{array}$ & $\begin{array}{l}3.37 \\
(0.93)\end{array}$ & $\begin{array}{l}3.39 \\
(0.54)\end{array}$ & - & $\begin{array}{l}3.02 \\
(0.72)\end{array}$ & $\begin{array}{l}2.94 \\
(0.77)\end{array}$ & $\begin{array}{l}3.40 \\
(1.03)\end{array}$ & $\begin{array}{l}3.16 \\
(1.14)\end{array}$ & - & $\begin{array}{l}3.16 \\
(0.91)\end{array}$ & $\begin{array}{l}2.99 \\
(1.19)\end{array}$ & $\begin{array}{l}3.73 \\
(1.04)\end{array}$ & $\begin{array}{l}3.64 \\
(1.02)\end{array}$ & - & $\begin{array}{l}3.11 \\
(1.27)\end{array}$ & $\begin{array}{l}2.89 \\
(0.97)\end{array}$ & ns & $\begin{array}{l}8.66, \\
p< \\
.001 \\
(0.10)\end{array}$ & ns \\
\hline
\end{tabular}

Note: degrees of freedom $(4,304)$ on time effects, $(8,304)$ on interactions, and $(2,76)$ on group effects, except concerning need for recovery, which was in the same model with performance-related outcomes, see the degrees of freedom from Table 3. 
Table 5. Results of repeated measures MANOVAs for effects across time, between groups (non-users, passive and active users), and for time $\times$ group interactions on job performance.

1) Non-users $(n=51)$

2) Passive users $(n=18)$

3) Active users $(n=10)$

Group
effect

Time effect

$\times$

effect

\begin{tabular}{|c|c|c|c|c|c|c|c|c|c|c|c|c|c|c|c|}
\hline Job & $\mathrm{T} 1$ & $\mathrm{~T} 2$ & $\mathrm{~T} 4$ & $\mathrm{~T} 5$ & $\mathrm{~T} 1$ & $\mathrm{~T} 2$ & T4 & T5 & $\mathrm{T} 1$ & $\mathrm{~T} 2$ & $\mathrm{~T} 4$ & T5 & & & \\
\hline & $\begin{array}{l}M \\
(S D)\end{array}$ & $\begin{array}{l}M \\
(S D)\end{array}$ & $\begin{array}{l}M \\
(S D)\end{array}$ & $\begin{array}{l}M \\
(S D)\end{array}$ & $\begin{array}{l}M \\
(S D)\end{array}$ & $\begin{array}{l}M \\
(S D)\end{array}$ & $\begin{array}{l}M \\
(S D)\end{array}$ & $\begin{array}{l}M \\
(S D)\end{array}$ & $\begin{array}{l}M \\
(S D)\end{array}$ & $\begin{array}{l}M \\
(S D)\end{array}$ & $\begin{array}{l}M \\
(S D)\end{array}$ & $\begin{array}{l}M \\
(S D)\end{array}$ & $\begin{array}{l}F, p, \\
\left(\eta p^{2}\right)\end{array}$ & $\begin{array}{l}F, p \\
\left(\eta p^{2}\right)\end{array}$ & $\begin{array}{l}F, p \\
\left(\eta p^{2}\right)\end{array}$ \\
\hline $\begin{array}{l}\text { Task } \\
\text { performance }\end{array}$ & $\begin{array}{l}7.75 \\
(1.31)\end{array}$ & $\begin{array}{l}7.53 \\
(0.97)\end{array}$ & $\begin{array}{l}7.17 \\
(1.53)\end{array}$ & $\begin{array}{l}7.37 \\
(1.38)\end{array}$ & $\begin{array}{l}7.61 \\
(0.98)\end{array}$ & $\begin{array}{l}6.94 \\
(1.99)\end{array}$ & $\begin{array}{l}6.81 \\
(2.21)\end{array}$ & $\begin{array}{l}7.24 \\
(1.41)\end{array}$ & $\begin{array}{l}6.70 \\
(1.49)\end{array}$ & $\begin{array}{l}6.82 \\
(1.76)\end{array}$ & $\begin{array}{l}7.49 \\
(0.86)\end{array}$ & $\begin{array}{l}7.73 \\
(0.92)\end{array}$ & ns & ns & ns \\
\hline $\begin{array}{l}\text { Concentration } \\
\text { capacity }\end{array}$ & $\begin{array}{l}5.18 \\
(1.31)\end{array}$ & $\begin{array}{l}5.12 \\
(1.23)\end{array}$ & $\begin{array}{l}5.26 \\
(0.96)\end{array}$ & $\begin{array}{l}5.04 \\
(1.03)\end{array}$ & $\begin{array}{l}5.11 \\
(1.23)\end{array}$ & $\begin{array}{l}5.05 \\
(1.40)\end{array}$ & $\begin{array}{l}5.09 \\
(1.30)\end{array}$ & $\begin{array}{l}5.09 \\
(0.77)\end{array}$ & $\begin{array}{l}4.80 \\
(1.48)\end{array}$ & $\begin{array}{l}4.58 \\
(1.13)\end{array}$ & $\begin{array}{l}5.24 \\
(1.03)\end{array}$ & $\begin{array}{l}5.25 \\
(1.28)\end{array}$ & ns & ns & ns \\
\hline $\begin{array}{l}\text { Creativity at } \\
\text { work }\end{array}$ & $\begin{array}{l}4.94 \\
(1.38)\end{array}$ & $\begin{array}{l}4.66 \\
(0.96)\end{array}$ & $\begin{array}{l}4.16 \\
(1.04)\end{array}$ & $\begin{array}{l}4.39 \\
(1.14)\end{array}$ & $\begin{array}{l}4.96 \\
(1.44)\end{array}$ & $\begin{array}{l}4.78 \\
(1.34)\end{array}$ & $\begin{array}{l}3.89 \\
(1.35)\end{array}$ & $\begin{array}{l}4.86 \\
(1.17)\end{array}$ & $\begin{array}{l}4.48 \\
(1.18)\end{array}$ & $\begin{array}{l}4.36 \\
(1.58)\end{array}$ & $\begin{array}{l}4.91 \\
(1.00)\end{array}$ & $\begin{array}{l}4.88 \\
(0.92)\end{array}$ & ns & $\begin{array}{l}2.79 \\
p= \\
.041 \\
(0.04)\end{array}$ & $\begin{array}{l}2.84 \\
p= \\
.011 \\
(0.07)\end{array}$ \\
\hline
\end{tabular}

Note: degrees of freedom $(3,228)$ on time effects, $(6,228)$ on interactions, and $(2,76)$ on group effects 
T1: Wednesday

$1 \frac{1}{2}$ weeks

before the

vacation
T3: Wednesday in the middle of

the vacation
T5: Wednesday

$11 \frac{1}{2}$ weeks after

the vacation

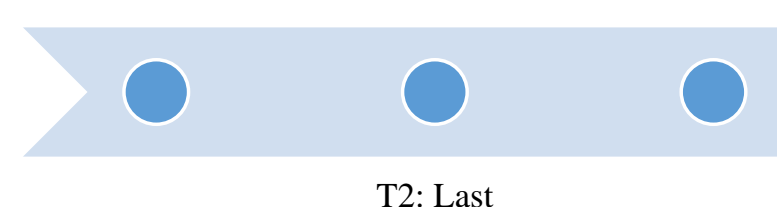

T2: Last

working day

before the

vacation

(Friday)
T4: Wednesday

in the first

working week

after the

vacation

Figure 1. Study design: Measurement points 


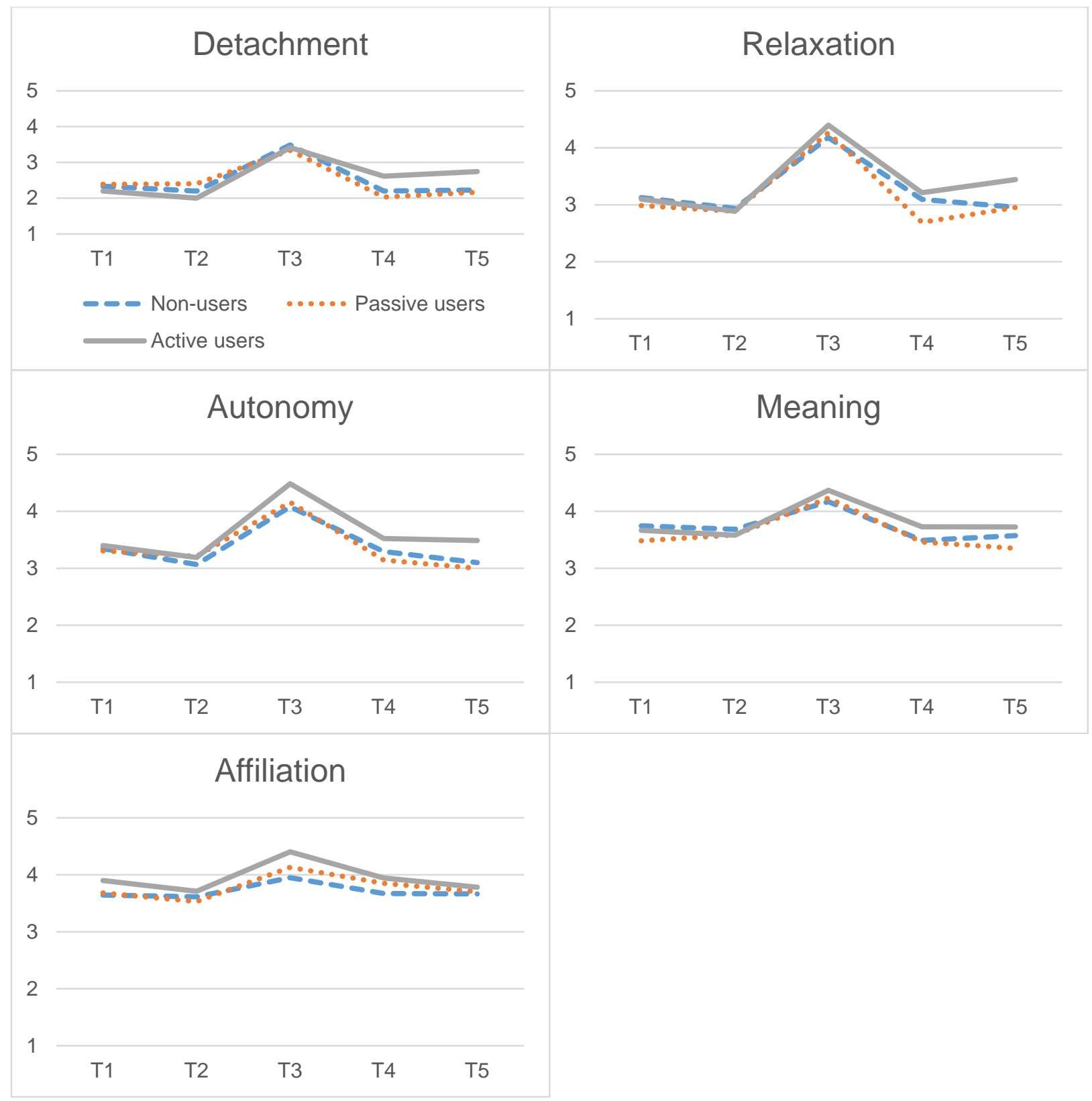

Figure 2. Changes in recovery experiences among non-users $(n=51)$, passive app users $(n=18)$, and active app users $(n=10)$ across the study period (T1-T5).

Note: T1: Wednesday 1.5 weeks before the vacation, T2: last working day (Friday) before the vacation, T3: during the vacation, T4: Wednesday of the first week after the vacation, T5: Wednesday 1.5 weeks after the vacation 


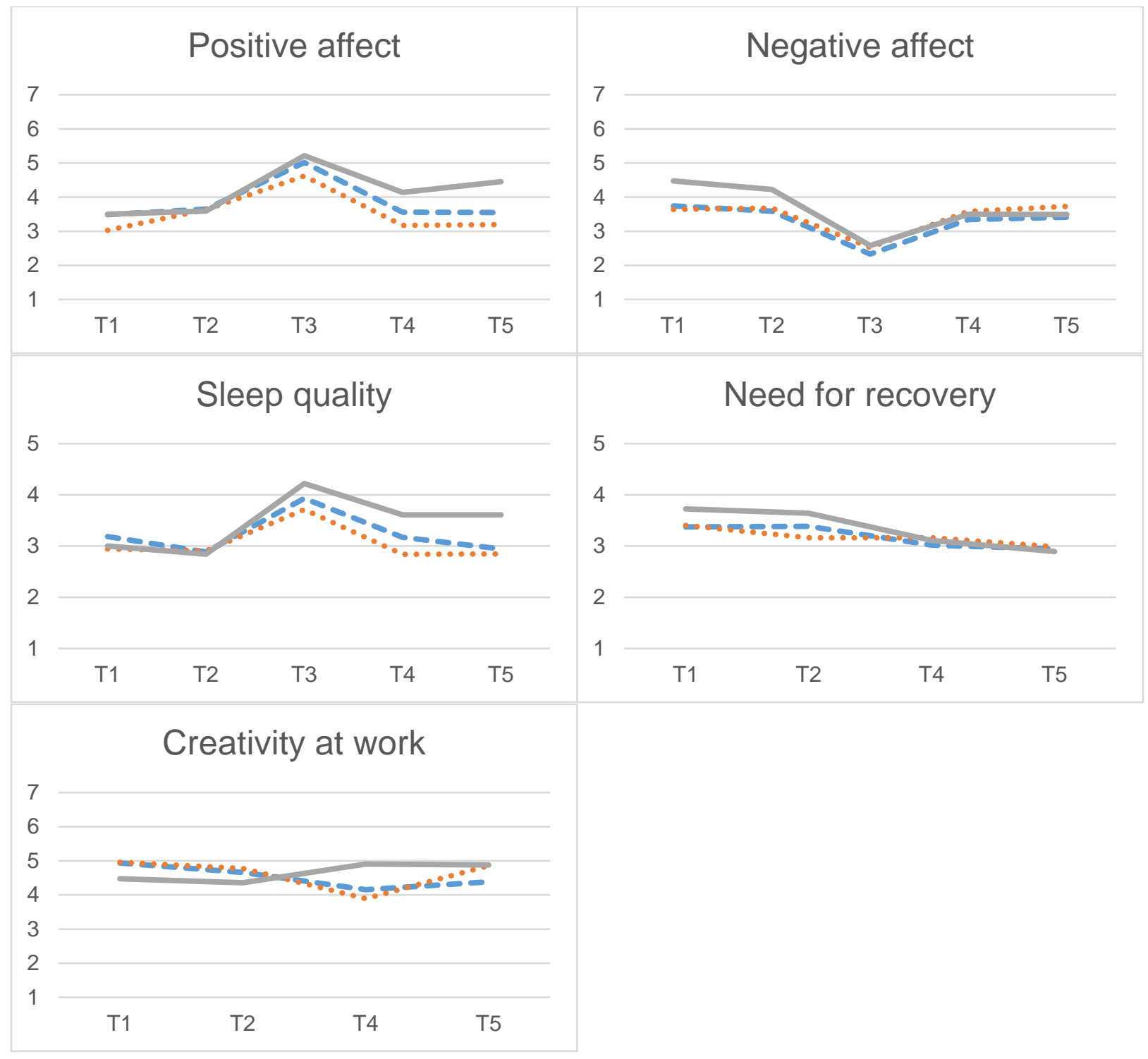

Figure 3. Changes in well-being and job performance among non-users $(n=51)$, passive app users ( $n=18)$, and active app users $(n=10)$ across the study period (T1-T5).

Note: T1: Wednesday 1.5 weeks before the vacation, T2: last working day (Friday) before the vacation, T3: during the vacation, T4: Wednesday of the first week after the vacation, T5: Wednesday 1.5 weeks after the vacation. 


\section{Implications for practice}

- It may be possible to support recovery from work, well-being, and job performance with simple, intentional activities presented in a self-guided smartphone app.

- In the future, the content of the Holidaily app could be transformed into more general recovery-promoting exercises (applied during work breaks, evening hours or at weekends), which could help alleviate work stress in hectic everyday life.

- Monitoring development in well-being with an app may help users to pay attention to recovery and well-being.

- Good usability of recovery-promoting apps is essential for smooth and enjoyable use.

- Smartphone interventions may not work for everyone: it is important to identify the target groups most likely to benefit from app use. 


\section{References}

Bennett, A. A., Bakker, A. B., \& Field, J. G. (2018). Recovery from work-related effort: A meta-analysis. Journal of Organizational Behavior, 39(3), 262-275.

Bolier, L., Haverman, M., Westerhof, G. J., Riper, H., Smit, F., \& Bohlmeijer, E. (2013). Positive psychology interventions: A meta-analysis of randomized controlled studies. BMC Public Health, 13(1), 119.

Butler, J., \& Kern, M. L. (2016). The PERMA-Profiler: A brief multidimensional measure of flourishing. International Journal of Wellbeing, 6(3), 1-48.

Carolan, S., Harris, P. R., \& Cavanagh, K. (2017). Improving employee well-being and effectiveness: Systematic review and meta-analysis of web-based psychological interventions delivered in the workplace. Journal of Medical Internet Research, 18(7), e271.

Chen, B., Vansteenkiste, M., Beyers, W., Boone, L., Deci, E. L., Van der Kaap-Deeder, J., ... Verstuyf, J. (2015). Basic psychological need satisfaction, need frustration, and need strength across four cultures. Motivation and Emotion, 39(2), 216-236.

Chen, C., \& Petrick, J. F. (2013). Health and wellness benefits of travel experiences: A literature review. Journal of Travel Research, 52(6), 709-719.

Cheng, S. K., \& Dizon, J. (2012). Computerised cognitive behavioural therapy for insomnia: A systematic review and meta-analysis. Psychotherapy and Psychosomatics, 81(4), 206-216.

De Bloom, J. (2012). How do vacations affect workers' health and well-being? Vacation (after-) effects and the role of vacation activities and experiences. Radboud University Nijmegen.

De Bloom, J. De, Geurts, S., \& Kompier, M. (2010). Vacation from work as prototypical recovery opportunity. Gedrag \& Organisatie, 23(4), 333-349.

De Bloom, J., Geurts, S. A. E., \& Kompier, M. A. J. (2013). Vacation (after-) effects on employee health and wellbeing, and the role of vacation activities, experiences and sleep. Journal of Happiness Studies, 14(2), 613633.

De Bloom, J., Geurts, S. A. E., \& Kompier, M. A. J. (2012). Effects of short vacations, vacation activities and experiences on employee health and well-being. Stress and Health, 28(4), 305-318. 
De Bloom, J., Geurts, S. A., Sonnentag, S., Taris, T., de Weerth, C., \& Kompier, M. A. (2011). How does a vacation from work affect employee health and well-being? Psychology \& Health, 26(12), 1606-1622.

De Bloom, J., Kompier, M., Geurts, S., de Weerth, C., Taris, T., \& Sonnentag, S. (2009). Do we recover from vacation? Meta-analysis of vacation effects on health and well-being. Journal of Occupational Health, 51(1), $13-25$.

De Bloom, J., Nawijn, J., Geurts, S., Kinnunen, U., \& Korpela, K. (2017). Holiday travel, staycations, and subjective well-being. Journal of Sustainable Tourism, 25(4), 573-588.

De Bloom, J., Ritter, S., Kühnel, J., Reinders, J., \& Geurts, S. (2014). Vacation from work: A “ticket to creativity”? Tourism Management, 44, 164-171.

De Bloom, J., Sianoja, M., Korpela, K., Tuomisto, M., Lilja, A., Geurts, S., \& Kinnunen, U. (2017). Effects of park walks and relaxation exercises during lunch breaks on recovery from job stress: two randomized controlled trials. Journal of Environmental Psychology, 51, 14-30.

Donker, T., Petrie, K., Proudfoot, J., Clarke, J., Birch, M. R., \& Christensen, H. (2013). Smartphones for smarter delivery of mental health programs: A systematic review. Journal of Medical Internet Research, 15(11), e247.

Ebert, D. D., Berking, M., Thiart, H., Riper, H., Laferton, J. A. C., Cuijpers, P., Lehr, D. (2015). Restoring depleted resources: Efficacy and mechanisms of change of an Internet-based unguided recovery training for better sleep and psychological detachment from work. Health Psychology, 34(S), 1240-1251.

Ebert, D. D., Lehr, D., Heber, E., Riper, H., Cuijpers, P., \& Berking, M. (2016). Internet- and mobile-based stress management for employees with adherence-focused guidance: Efficacy and mechanism of change. Scandinavian Journal of Work, Environment and Health, 42(5), 382-394.

Emmons, R. A., \& Crumpler, C. A. (2000). Gratitude as a human strength: Appraising the evidence. Journal of Social and Clinical Psychology, 19(1), 56-69.

Fernet, C., Guay, F., Senécal, C., \& Austin, S. (2012). Predicting intraindividual changes in teacher burnout: The role of perceived school environment and motivational factors. Teaching and Teacher Education, 28(4), 514525.

Fiordelli, M., Diviani, N., \& Schulz, P. J. (2013). Mapping m-health research: A decade of evolution. Journal of 
Medical Internet Research, 15(5), e95.

Firth, J., Torous, J., Nicholas, J., Carney, R., Rosenbaum, S., \& Sarris, J. (2017). Can smartphone mental health interventions reduce symptoms of anxiety? A meta-analysis of randomized controlled trials. Journal of Affective Disorders, 218, 15-22.

Fredrickson, B. L. (2001). The role of positive emotions in positive psychology. The broaden-and-build theory of positive emotions. The American Psychologist, 56(3), 218-226.

Fritz, C., \& Sonnentag, S. (2006). Recovery, well-being, and performance-related outcomes: The role of workload and vacation experiences. Journal of Applied Psychology, 91(4), 936-945.

Gander, F., Proyer, R. T., \& Ruch, W. A. (2018). Placebo-controlled online study on potential mediators of a pleasure-based positive psychology Intervention: The role of emotional and cognitive components. Journal of Happiness Studies, 19, 2035-2048.

Garrick, A. M., Mak, A. S., Cathcart, S., Winwood, P. C., Bakker, A. B., \& Lushington, K. (2018). Non-work time activities predicting teachers’ work-related fatigue and engagement: An effort-recovery approach. Australian Psychologist, 53(3), 243-252.

George, J. M., \& Zhou, J. (2001). When openness to experience and conscientiousness are related to creative behavior: An interactional approach. Journal of Applied Psychology, 86(3), 513-524.

Geurts, S. A. E., \& Sonnentag, S. (2006). Recovery as an explanatory mechanism in the relation between acute stress reactions and chronic health impairment. Scandinavian Journal of Work, Environment and Health, 32(6), 482-492.

Hahn, V. C., Binnewies, C., Sonnentag, S., \& Mojza, E. J. (2011). Learning how to recover from job stress: Effects of a recovery training program on recovery, recovery-related self-efficacy, and well-being. Journal of Occupational Health Psychology, 16(2), 202-216.

Hartig, T., Catalano, R., Ong, M., \& Syme, S. L. (2013). Vacation, collective restoration, and mental health in a population. Society and Mental Health, 3(3), 221-236.

Haug, T., Nordgreen, T., Öst, L. G., \& Havik, O. E. (2012). Self-help treatment of anxiety disorders: A metaanalysis and meta-regression of effects and potential moderators. Clinical Psychology Review, 32(5), 425- 
445.

Heber, E., Ebert, D. D., Lehr, D., Cuijpers, P., Berking, M., Nobis, S., \& Riper, H. (2017). The benefit of web- and computer-based interventions for stress: A systematic review and meta-analysis. Journal of Medical Internet Research, 19(2), e32.

Hofboll, S. E. (1989). Conservation of resources: A new attempt at conceptualizing stress. American Psychologist, 44, 513-524.

Hoffmann, A., Christmann, C. A., \& Bleser, G. (2017). Gamification in stress management apps: A critical app review. JMIR Serious Games, 5(2), e13.

Hülsheger, U. R., Lang, J. W., Depenbrock, F., Fehrmann, C., Zijlstra, F. R., \& Alberts, H. J. (2014). The power of presence: The role of mindfulness at work for daily levels and change trajectories of psychological detachment and sleep quality. Journal of Applied Psychology, 99(6), 1113-1128.

Iwasaki, Y. (2008). Pathways to meaning-making through leisure-like pursuits in global contexts. Journal of Leisure Research, 40(2), 231-249.

Jaussi, K. S., Randel, A. E., \& Dionne, S. D. (2007). I am, I think I can, and I do: The role of personal identity, selfefficacy, and cross-application of experiences in creativity at work. Creativity Research Journal, 19(2-3), 247-258.

Johnson, D., Deterding, S., Kuhn, K.-A., Staneva, A., Stoyanov, S., \& Hides, L. (2016). Gamification for health and wellbeing: A systematic review of the literature. Internet Interventions, 6, 89-106.

Kessler, R. C., Barber, C., Beck, A., Berglund, P., Cleary, P. D., McKenas, D., Wang, P. (2003). The World Health Organization Health and Work Performance Questionnaire (HPQ). Journal of Occupational and Environmental Medicine, 45(2), 156-174.

Klassen, R. M., \& Chiu, M. M. (2011). The occupational commitment and intention to quit of practicing and preservice teachers: Influence of self-efficacy, job stress, and teaching context. Contemporary Educational Psychology, 36(2), 114-129.

Kühnel, J., \& Sonnentag, S. (2011). How long do you benefit from vacation? A closer look at the fade-out of vacation effects. Journal of Organizational Behavior, 32(1), 125-143. 
Kyriacou, C. (2001). Teacher stress: directions for future research. Educational Review, 53(1), 27-35.

Königbauer, J., Letsch, J., Doebler, P., Ebert, D., \& Baumeister, H. (2017). Internet- and mobile-based depression interventions for people with diagnosed depression: a systematic review and meta-analysis. Journal of affective disorders, 223, 28-40.

La Guardia, J. G., Ryan, R. M., Couchman, C. E., \& Deci, E. L. (2000). Within-person variation in security of attachment: A self-determination theory perspective on attachment, need fulfillment, and well-being. Journal of Personality and Social Psychology, 79(3), 367-384.

Lehr, D., Geraedts, A., Persson Asplund, R., Khadjesari, Z., Heber, E., de Bloom, J., Funk, B. (2016). Occupational e-mental health: Current approaches and promising perspectives for promoting mental health in workers. In Wiencke, M., et al. (Eds.), Healthy at work (pp. 257-281). Springer, Cham.

Lehr, D., De Bloom, J., \& Syrek, C. (2016-2018). “Holidaily”: Smartphone app for better recovery from stressful work before, during and after vacation. Funded by the German health insurance company Barmer GEK

Lyubomirsky, S., \& Layous, K. (2013). How do simple positive activities increase well-being? Current Directions in Psychological Science, 22(1), 57-62.

Lyubomirsky, S., Sousa, L., \& Dickerhoof, R. (2006). The costs and benefits of writing, talking, and thinking about life’s triumphs and defeats. Journal of Personality and Social Psychology, 90(4), 692-708.

March, S., Day, J., Ritchie, G., Rowe, A., Gough, J., Hall, T., ... \& Ireland, M. (2018). Attitudes toward e-mental health services in a community sample of adults: online survey. Journal of Medical Internet Research, 20(2), e59.

Mazzucchelli, T. G., Kane, R. T., \& Rees, C. S. (2010). Behavioral activation interventions for well-being: A metaanalysis. Journal of Positive Psychology, 5(2), 105-121.

Mehrotra, S., \& Tripathi, R. (2018). Recent developments in the use of smartphone interventions for mental health. Current Opinion in Psychiatry, 31(5), 379-388.

Meijman, T. F., \& Mulder, G. (1998). Psychological aspects of workload. In Drenth, P.J.D, Thierry, H., \& de Wolff, C.J. (Eds.), Handbook of work and organizational psychology, Volume 2. 
Meyers, M. C., van Woerkom, M., \& Bakker, A. B. (2012). The added value of the positive: A literature review of positive psychology interventions in organizations. European Journal of Work and Organizational Psychology, 22(5), 618-632.

Michel, A., Bosch, C., \& Rexroth, M. (2014). Mindfulness as a cognitive-emotional segmentation strategy: An intervention promoting work-life balance. Journal of Occupational and Organizational Psychology, 87(4), 733-754.

Nawijn, J., De Bloom, J., \& Geurts, S. (2013). Pre-vacation time: Blessing or burden? Leisure Sciences, 35(1), 3344.

Newman, D. B., Tay, L., \& Diener, E. (2014). Leisure and subjective well-being: A model of psychological mechanisms as mediating factors. Journal of Happiness Studies, 15(3), 555-578.

Park, J. H., Kang, S. Y., \& Jeon, H. S. (2013). The effect of using smart-phones on neck and shoulder muscle activities and fatigue. Physical Therapy Korea, 20(3), 19-26.

Reizer, A., \& Mey-Raz, N. (2018). Slowing down vacation fade-out effects. International Journal of Stress Management.Advance online publication.

Richards, D., \& Richardson, T. (2012). Computer-based psychological treatments for depression: A systematic review and meta-analysis. Clinical Psychology Review, 32(4), 329-342.

Richardson, K. M., \& Rothstein, H. R. (2008). Effects of occupational stress management intervention programs: A meta-analysis. Journal of Occupational Psychology, 13(1), 69-93.

Rook, J. W., \& Zijlstra, F. R. (2006). The contribution of various types of activities to recovery. European Journal of Work and Organizational Psychology, 15(2), 218-240.

Ryan, R. M., \& Deci, E. L. (2000). Self-determination theory and the facilitation of intrinsic motivation, social development, and well-being. American Psychologist, 55(1), 68-78.

Schafer, J. L., \& Graham, J. W. (2002). Missing data: our view of the state of the art. Psychological Methods, 7(2), $147-177$.

Schulenberg, S. E., Schnetzer, L. W., \& Buchanan, E. M. (2011). The purpose in life test-short form: Development and psychometric support. Journal of Happiness Studies, 12(5), 861-876. 
Seligman, M. E. P., Steen, T. A., Park, N., \& Peterson, C. (2005). Positive psychology progress: empirical validation of interventions. American Psychologist, 60(5), 410-421.

Sheldon, K. M., \& Niemiec, C. P. (2006). It's not just the amount that counts: Balanced need satisfaction also affects well-being. Journal of Personality and Social Psychology, 91(2), 331-341.

Sianoja, M., Syrek, C. J., de Bloom, J., Korpela, K., \& Kinnunen, U. (2017). Enhancing daily well-being at work through lunchtime park walks and relaxation exercises: Recovery experiences as mediators. Journal of Occupational Health Psychology, 23(3), 428-442.

Sin, N. L., \& Lyubomirsky, S. (2009). Enhancing well-being and alleviating depressive symptoms with positive psychology interventions: A practice-friendly meta-analysis. Journal of Clinical Psychology, 65(5), 467-487.

Skaalvik, E. M., \& Skaalvik, S. (2015). Job satisfaction, stress and coping strategies in the teaching profession-what do teachers say? International Education Studies, 8(3), 181-192.

Skaalvik, E. M., \& Skaalvik, S. (2017). Still motivated to teach? A study of school context variables, stress and job satisfaction among teachers in senior high school. Social Psychology of Education, 20(1), 15-37.

Smyth, A., Syrek, C., Reins, J. A., Domin, M., Janneck, M., \& Lehr, D. (2018). User experience predicts the effectiveness of a gamified recovery app. Prävention Und Gesundheitsförderung, 13(4), 319-326.

Sonnentag, S., \& Fritz, C. (2007). The recovery experience questionnaire: Development and validation of a measure for assessing recuperation and unwinding from work. Journal of Occupational Health Psychology, 12(3), 204-221.

Sonnentag, S., \& Fritz, C. (2015). Recovery from job stress: The stressor-detachment model as an integrative framework. Journal of Organizational Behavior, 36(S1), S72-S103.

Sonnentag, S., Venz, L., \& Casper, A. (2017). Advances in recovery research: What have we learned? What should be done next? Journal of Occupational Health Psychology, 22(3), 365-380.

Syvänen, A., Mäkiniemi, J.-P., Syrjä, S., Heikkilä-Tammi, K., \& Viteli, J. (2016). When does the educational use of ICT become a source of technostress for Finnish teachers? Seminar.Net, 12(2), 96-109.

Thiart, H., Lehr, D., Ebert, D. D., Berking, M., \& Riper, H. (2015). Log in and breathe out: internet-based recovery training for sleepless employees with work-related strain-results of a randomized controlled trial. 
Scandinavian Journal of Work, Environment \& Health, 41(2), 164-174.

Tierney, P., Farmer, S. M., \& Graen, G. B. (1999). An examination of leadership and employee creativity: The relevance of traits and relationships. Personnel Psychology, 52(3), 591-620.

Van den Broeck, A., Vansteenkiste, M., De Witte, H., Soenens, B., \& Lens, W. (2010). Capturing autonomy, competence, and relatedness at work: Construction and initial validation of the Work-related Basic Need Satisfaction scale. Journal of Occupational and Organizational Psychology, 83(4), 981-1002.

Van Laethem, M., Van Vianen, A. E., \& Derks, D. (2018). Daily fluctuations in smartphone use, psychological detachment, and work engagement: The role of workplace telepressure. Frontiers in Psychology, 9:1808.

Van Veldhoven, M. (2003). Measurement quality and validity of the "need for recovery scale.” Occupational and Environmental Medicine, 60 (suppl 1), i2-i9.

Verbeek, J., Ruotsalainen, J., Laitinen, J., Korkiakangas, E., Lusa, S., Mänttäri, S., \& Oksanen, T. (2018). Interventions to enhance recovery in healthy workers; a scoping review. Occupational Medicine, kqy141, 210.

Watson, D., \& Anna Clark, L. (1999). The PANAS-X: Manual for the Positive and Negative Affect Schedule Expanded Form. Ames: The University of Iowa.

Wendsche, J., \& Lohmann-Haislah, A. (2017). A meta-analysis on antecedents and outcomes of detachment from work. Frontiers in Psychology, 7, 2072.

Zijlstra, F. R. H., \& Sonnentag, S. (2006). After work is done: Psychological perspectives on recovery from work. European Journal of Work and Organizational Psychology, 15(2), 129-138.

Åkerstedt, T., Hume, K., Minors, D., \& Waterhouse, J. (1994). The subjective meaning of good sleep. An intraindividual approach using the Karolinska Sleep Diary. Perceptual and Motor Skills, 79(1), 287-296. 


\section{English Summary}

The aim of this study was to investigate whether beneficial vacation effects can be strengthened and prolonged with a smartphone-based intervention. In a four-week longitudinal study among 79 Finnish teachers, we investigated the development of recovery, well-being, and job performance before, during, and after a one-week vacation in three groups: non-users $(n=51)$, passive $(n=18)$ and active ( $n=10)$ users. Participants were instructed to make active use of a recovery app (called Holidaily) and complete five digital questionnaires. Most recovery experiences and well-being indicators increased during the vacation. Job performance and concentration capacity showed no significant time effects. Among active app users, creativity at work increased from baseline to after the vacation, whereas among non-users it decreased and among passive users it decreased a few days after the vacation but increased again one and a half weeks after the vacation. The fading of beneficial vacation effects on negative affect seems to have been slower among active app users. Only few participants used the app actively. Still, results suggest that a smartphone-based recovery intervention may support beneficial vacation effects.

\section{Keywords}

recovery from work, vacations, occupational e-mental health, recovery intervention, smartphone-based intervention 
Appendix 1: Screenshots of main functionalities in the Holidaily app

a) Adding a holiday in the app

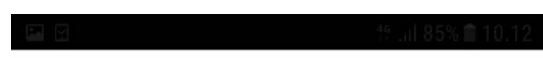

$\leftarrow \quad$ Add a holiday

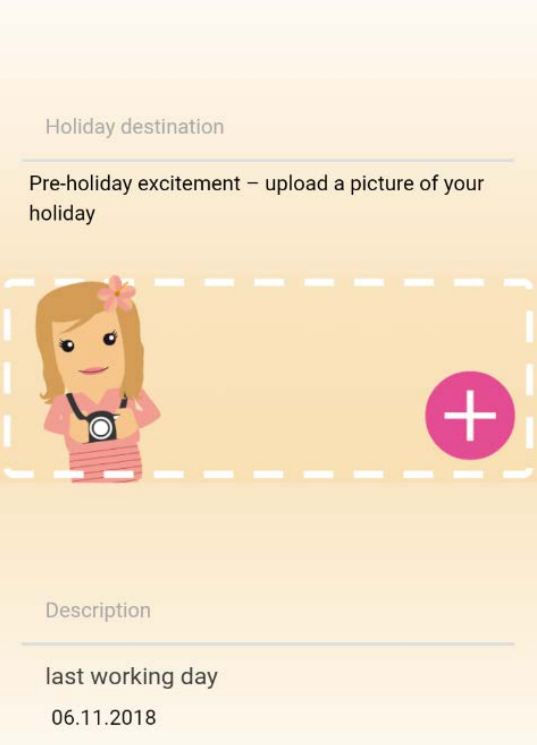

first day of holiday

07.11.2018 b) Home screen after adding a holiday

c) Daily example 1

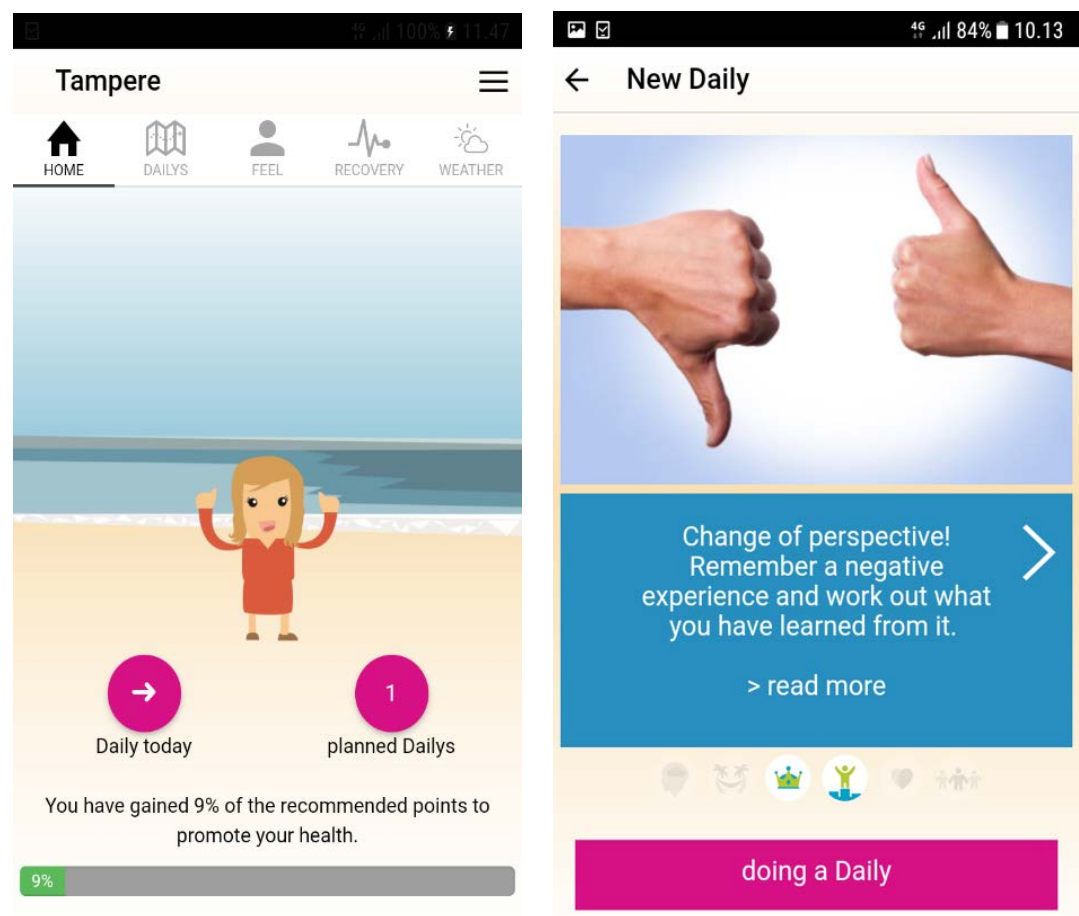

d) Daily example 2

e) View of a completed Daily

f) Well-being ratings

$\leftarrow$ New Daily
Effort: medium
Change of perspective! Remember a
negative experience and work out
what you have learned from it.
Think of a negative experience and try to
consider this experience from a different angle.
The majority of our negative experiences also
involve some positive elements. For example,
after the initial shock of being sacked, it may
lead to personal growth and space to consider
working for a new branch or sector which
previously would not have considered. There is
always something to be gained from a negative
experience. What have you learned from your
past negative experiences?
do Daily

$\begin{array}{ll}\text { 回 } \mathrm{G} & \text { 46. } 27 \%=16.19 \\ \leftarrow \text { done } & \end{array}$
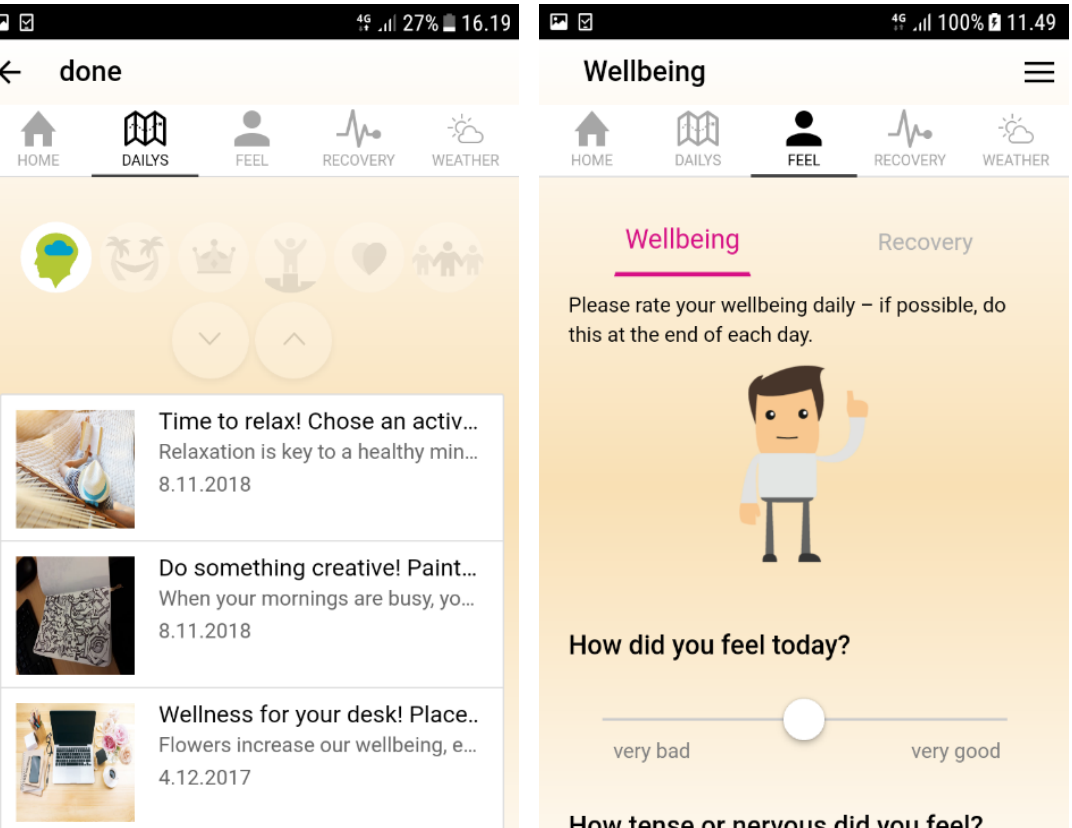

Please rate your wellbeing daily - if possible, do this at the end of each day.

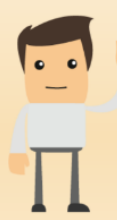

How did you feel today?

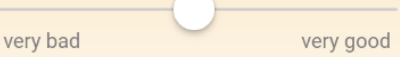

How tense or nervous did you feel?

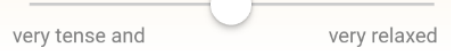

